\title{
Advances in understanding large-scale responses of the water cycle to climate change
}

\author{
Richard P. Allan, ${ }^{1}$ (D) Mathew Barlow, ${ }^{2}$ (D) Michael P. Byrne, ${ }^{3,4}$ (D) Annalisa Cherchi, ${ }^{5}$ (D) \\ Hervé Douville, ${ }^{6}$ (D) Hayley J. Fowler, ${ }^{7}$ (D) Thian Y. Gan, ${ }^{8}$ (D) Angeline G. Pendergrass, ${ }^{9}$ (ID \\ Daniel Rosenfeld, ${ }^{10,11}$ (D) Abigail L. S. Swann, ${ }^{12}$ (iD Laura J. Wilcox, ${ }^{13}$ (iD and Olga Zolina ${ }^{14,15}$ \\ ${ }^{1}$ Department of Meteorology and National Centre for Earth Observation, University of Reading, Reading, United Kingdom. \\ ${ }^{2}$ Department of Environmental Earth and Atmospheric Sciences, University of Massachusetts Lowell, Lowell, Massachusetts. \\ ${ }^{3}$ School of Earth and Environmental Science, University of St Andrews, St Andrews, United Kingdom. ${ }^{4}$ Department of Physics, \\ University of Oxford, Oxford, United Kingdom. ${ }^{5}$ Istituto Nazionale di Geofisica e Vulcanologia Sezione di Bologna, INGV, \\ Bologna, Italy. ${ }^{6}$ Centre National de Recherches Météorologiques, Météo-France/CNRS, Toulouse, France. ${ }^{7}$ University of \\ Newcastle, Newcastle upon Tyne, United Kingdom. ${ }^{8}$ University of Alberta, Edmonton, Alberta, Canada. ${ }^{9}$ National Center for \\ Atmospheric Research, Boulder, Colorado. ${ }^{10}$ Institute of Earth Sciences, The Hebrew University of Jerusalem, Jerusalem, \\ Israel. ${ }^{11}$ School of Atmospheric Sciences, Nanjing University, Nanjing, China. ${ }^{12}$ University of Washington, Seattle, \\ Washington. ${ }^{13}$ National Centre for Atmospheric Science, Department of Meteorology, University of Reading, Reading, United \\ Kingdom. ${ }^{14}$ L'Institut des Géosciences de l'Environnement/Centre National de la Recherche Scientifique, L'Université \\ Grenoble Alpes, Grenoble, France. ${ }^{15}$ P. P. Shirshov Institute of Oceanology, Russian Academy of Sciences, Moscow, Russia
}

Address for correspondence: Richard P. Allan, Department of Meteorology and National Centre for Earth Observation, University of Reading, Whiteknights, Earley Gate, PO Box 243, Reading RG6 6BB, United Kingdom. r.p.allan@reading.ac.uk

Globally, thermodynamics explains an increase in atmospheric water vapor with warming of around $7 \% /{ }^{\circ} \mathrm{C}$ near to the surface. In contrast, global precipitation and evaporation are constrained by the Earth's energy balance to increase at $\sim 2-3 \% /{ }^{\circ} \mathrm{C}$. However, this rate of increase is suppressed by rapid atmospheric adjustments in response to greenhouse gases and absorbing aerosols that directly alter the atmospheric energy budget. Rapid adjustments to forcings, cooling effects from scattering aerosol, and observational uncertainty can explain why observed global precipitation responses are currently difficult to detect but are expected to emerge and accelerate as warming increases and aerosol forcing diminishes. Precipitation increases with warming are expected to be smaller over land than ocean due to limitations on moisture convergence, exacerbated by feedbacks and affected by rapid adjustments. Thermodynamic increases in atmospheric moisture fluxes amplify wet and dry events, driving an intensification of precipitation extremes. The rate of intensification can deviate from a simple thermodynamic response due to in-storm and larger-scale feedback processes, while changes in large-scale dynamics and catchment characteristics further modulate the frequency of flooding in response to precipitation increases. Changes in atmospheric circulation in response to radiative forcing and evolving surface temperature patterns are capable of dominating water cycle changes in some regions. Moreover, the direct impact of human activities on the water cycle through water abstraction, irrigation, and land use change is already a significant component of regional water cycle change and is expected to further increase in importance as water demand grows with global population.

Keywords: climate change; water cycle; precipitation; land surface; radiative forcing

\section{Introduction}

The global water cycle describes a continual circulation of water through Earth's atmosphere, surface and subsurface that taps into the vast stores residing in the ocean, large bodies of ice, and deep within the ground. This cycle also determines smaller, more transient, yet life-sustaining, stores in rivers and lakes, the upper layers of soil and rock, as well as within animals and vegetation (Fig. 1A). Precipitation over land is strongly dependent on the transport of water vapor from the ocean ${ }^{1}$ and the return flow is primarily through rivers (Fig. 1B). 


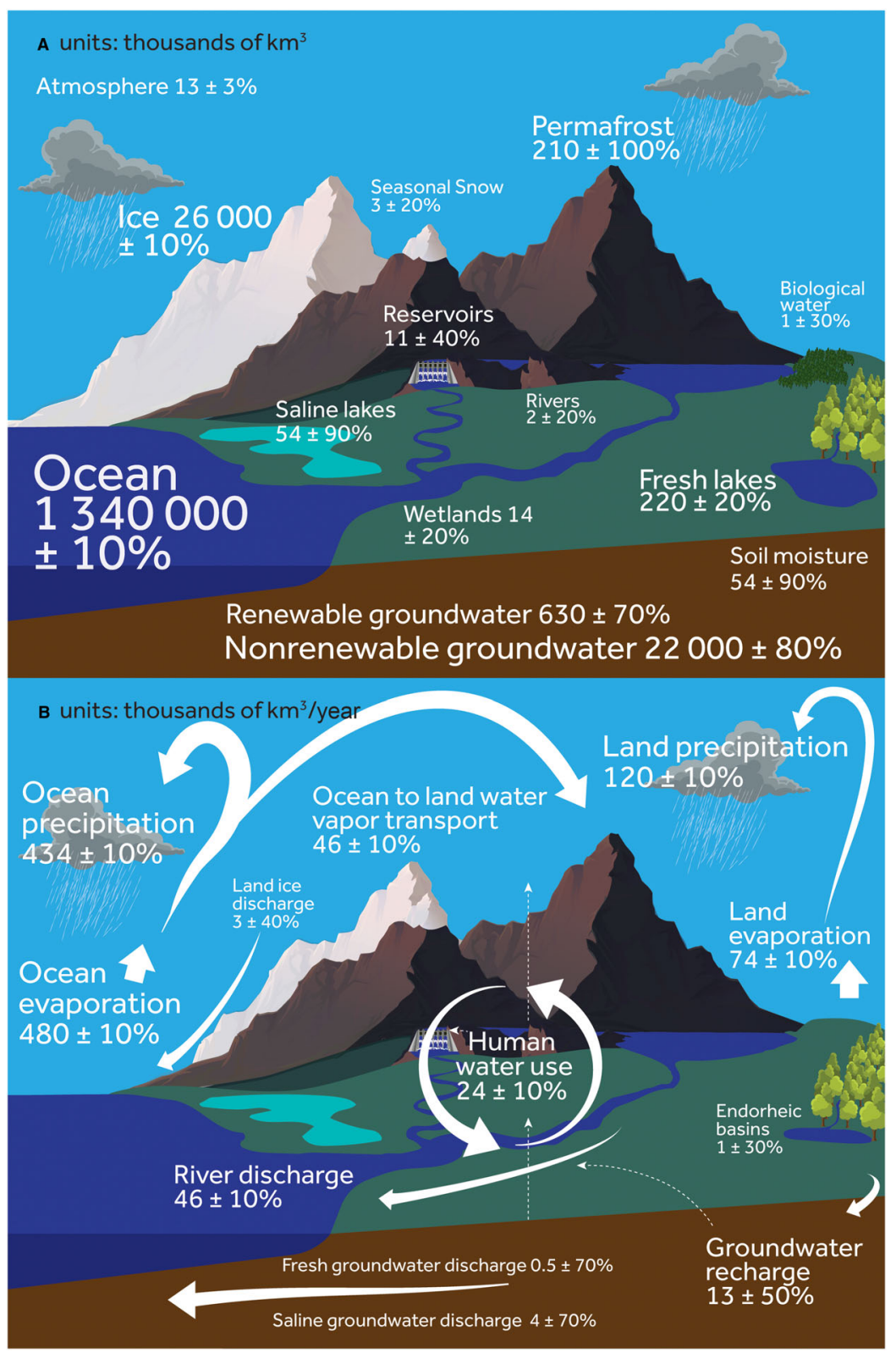

Figure 1. Depiction of the global water cycle: (A) stores (in thousands of $\mathrm{km}^{3}$ ) and (B) fluxes (thousands of $\mathrm{km}^{3}$ per year) based on previous assessments ${ }^{7,14,15}$ with minor adjustments for fresh groundwater flows ${ }^{16}$ and increases in precipitation and evaporation within quoted uncertainty based on observational evidence. ${ }^{17}$

The water cycle is influenced by natural variations in the sun and volcanic eruptions, as well as fluctuations internal to the climate system, and there is abundant evidence from the paleoclimate record of substantial past changes. ${ }^{2-4}$ Water cycle changes are increasingly becoming dominated by human activities, indirectly through climatic response to emissions of greenhouse gases and aerosol particles but also directly from interference with the land surface and the extraction of water from the ground and river systems (Fig. 1B) for agricultural, industrial, and domestic use. ${ }^{5-7}$

While global mean precipitation changes are determined by Earth's energy balance, regional 
changes are dominated by the transport of water vapor and dynamical processes, ${ }^{1}$ particularly at scales smaller than $\sim 4000 \mathrm{~km}^{8}$ Changes in weather patterns are further determined by altering heating and cooling patterns throughout the atmosphere and across the planet's surface. As the climate changes, these competing constraints operating at global and local scales alter key water cycle characteristics, such as precipitation frequency, intensity, and duration..${ }^{9} 10$ Future water availability, for use by societies and the ecosystems upon which they depend, is further influenced by increased evaporative demand by the atmosphere, ${ }^{11}$ but also an increased efficiency of water use by plants in response to elevated $\mathrm{CO}_{2}$ levels. ${ }^{12,13}$ Societies experience impacts through localized changes in water availability that are controlled by large-scale atmospheric circulation, as well as smaller scale physical processes. At regional to local scales, water cycle changes, therefore, result from the interplay between multiple drivers $\left(\mathrm{CO}_{2}\right.$, aerosols, land use change, and human water use). A primary focus here is on reviewing recent advances in understanding how these complex interactions are expected to determine responses in the global water cycle.

\section{Hydrological sensitivity at the global scale}

The Clausius-Clapeyron equation is a dominating thermodynamic constraint on atmospheric water vapor. Prevalent increases in atmospheric water vapor with warming ${ }^{18}$ drive powerful amplifying climate feedbacks, intensify atmospheric moisture transport and associated heavy precipitation events, and increase atmospheric absorption of sunlight and emission of infrared radiation to the surface that modulate global-scale evaporation and precipitation responses. ${ }^{19,20}$ Simulations and observations confirm a thermodynamic increase in water vapor close to $7 \% /{ }^{\circ} \mathrm{C}$ at low altitudes when averaged over global scales. ${ }^{21}$ This sensitivity varies depending on the radiative forcing agent and associated warming pattern: for column integrated water vapor, it ranges from $6.4 \pm 1.5 \% /{ }^{\circ} \mathrm{C}^{a}$ for sulfate aerosol forcing to $9.8 \pm 3.3 \% /{ }^{\circ} \mathrm{C}$ for black carbon, based on idealized modeling. ${ }^{22}$ Changes over global land are below the

${ }^{a} 5-95 \%$ confidence range is used unless otherwise stated, estimated as $1.645 \times$ standard deviation across models. thermodynamic response since relative humidity is expected to decrease due to greater land-sea warming contrast ${ }^{23}$ that is amplified by land surface feedbacks. ${ }^{24}$ Multimodel coupled CMIP5 simulations underestimate declining relative humidity observed over global land. ${ }^{25,26}$ This discrepancy also applies to atmosphere-only experiments applying observed sea surface temperature (SST): a single model simulated a -0.05 to $-0.25 \% /$ decade trend (1996-2015) compared with an observed estimate of -0.4 to $-0.8 \% /$ decade. ${ }^{25}$ It is not clear if this discrepancy is explained by potential deficiencies in representing ocean to land moisture transport, ${ }^{27}$ land-atmosphere coupling, ${ }^{24}$ or inhomogeneity of the observational records. ${ }^{28}$

In contrast to water vapor, global mean evaporation and precipitation are tightly linked to the atmospheric and surface energy budgets rather than the Clausius-Clapeyron equation. ${ }^{29,30}$ Latent heat released through precipitation is balanced by the net atmospheric longwave radiative cooling minus the heating from absorbed sunlight and sensible heat flux from the surface (Fig. 2A). Complementary energetic arguments apply for surface evaporation. ${ }^{31,32}$ The total global mean precipitation response to warming, or apparent hydrological sensitivity $\left(\eta_{a}\right.$, Fig. 2 F) includes fast adjustments that scale with radiative forcing and slow temperature-driven responses to the radiative forcings. ${ }^{33-35}$ The fast response is caused by near-instantaneous changes in the atmospheric energy budget and atmospheric properties (e.g., temperature, clouds, and water vapor; Fig. 2C) in direct response to the radiative effects of a forcing agent. ${ }^{36} \mathrm{~A}$ further relatively fast response involves the land-surface temperature (Fig. 2D), which responds more rapidly to radiative forcing than ocean SST. ${ }^{35,37}$ The land surface response depends on the partitioning of increased net surface radiation between latent and sensible heat (and thereby on the land hydrology) as well as the direct response of plants to elevated $\mathrm{CO}_{2} \cdot{ }^{24,38}$ The slower global temperature-dependent precipitation response, or hydrological sensitivity ( $\eta$, Fig. $2 F$ ), is driven by the increased atmospheric radiative cooling rate of a warming atmosphere (Fig. 2E).

The fast and slow responses in global precipitation can be illustrated with idealized experiments as part of the 6th phase of the Coupled Model Intercomparison Project (CMIP6) in which atmospheric 

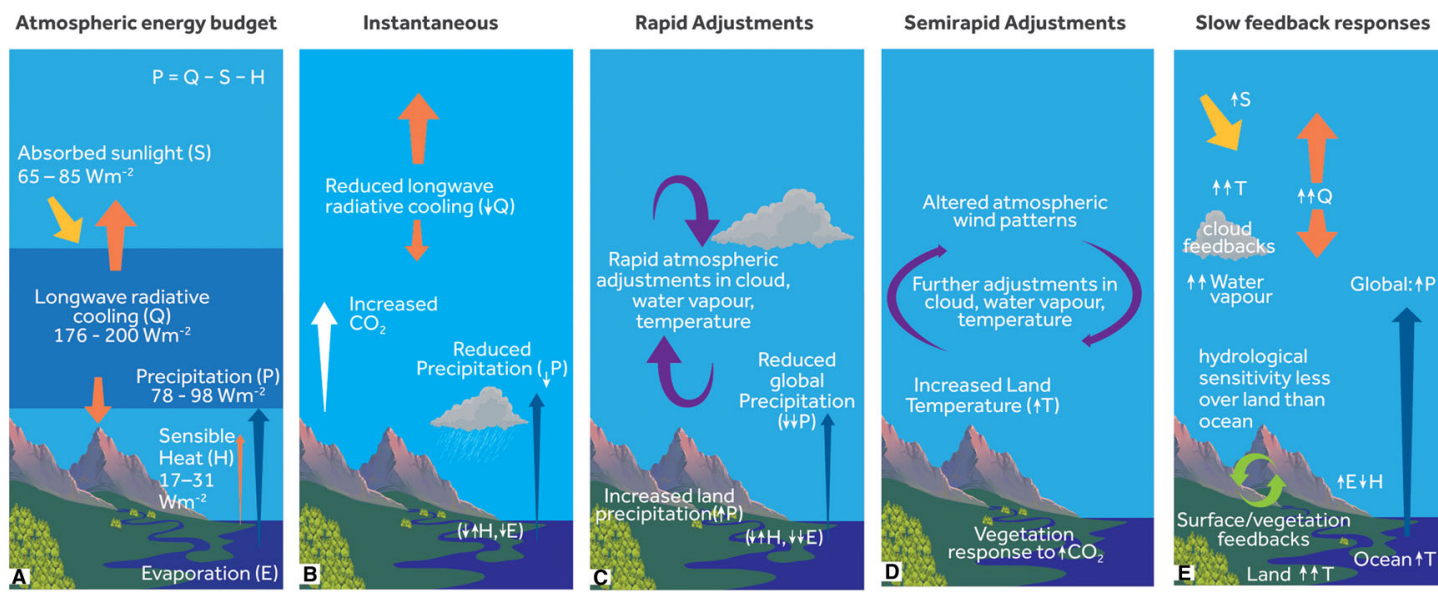

$\eta$-hydrological sensitivity

$\eta_{\mathrm{a}}$-apparent hydrological sensitivity

Reduced precipitation globally
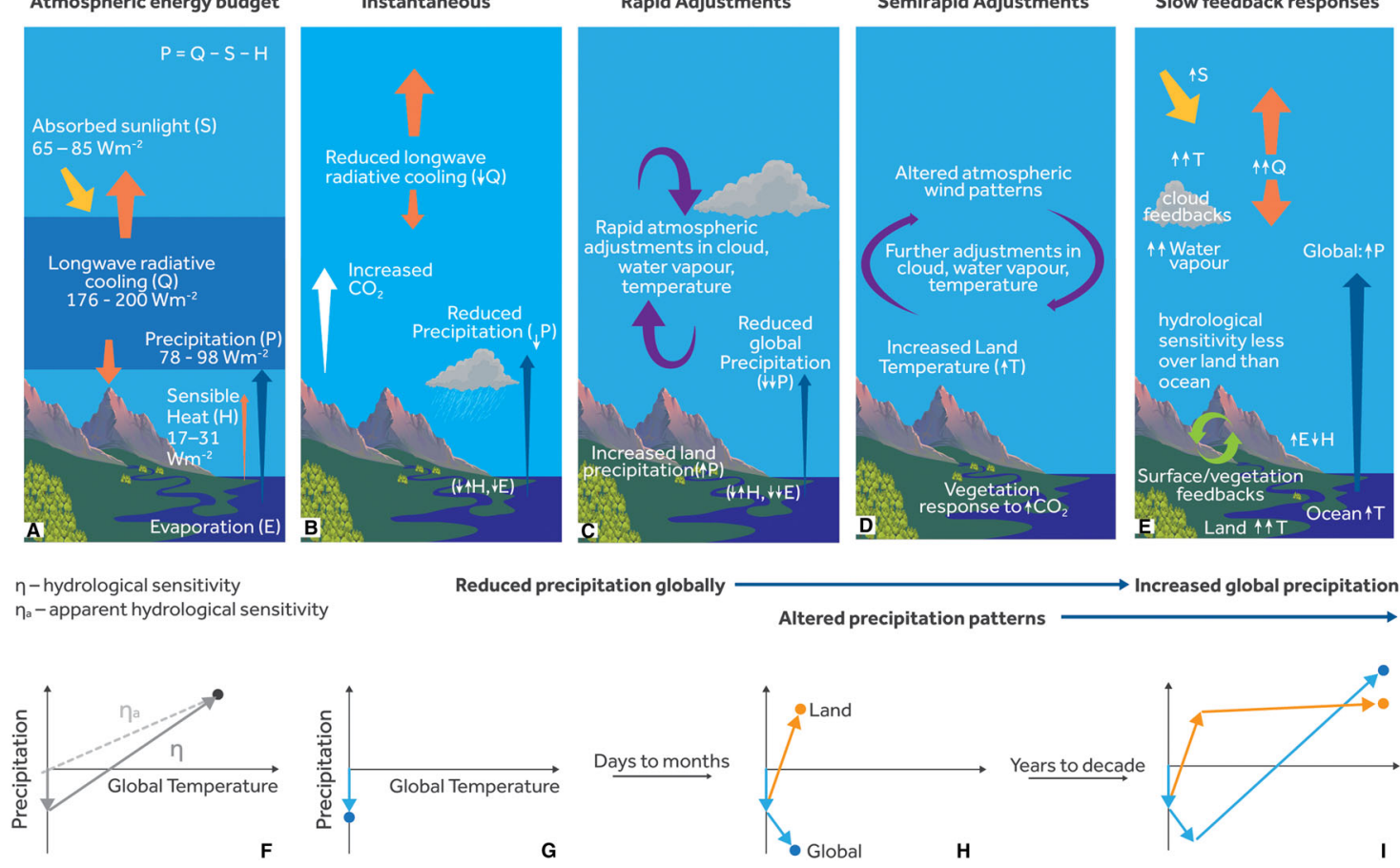

Figure 2. Schematic representation of responses of the atmospheric energy balance and global precipitation to increases in $\mathrm{CO}_{2}$. The energy budget of the atmosphere (A) responds instantaneously to radiative forcings (B), which leads to rapid atmospheric adjustments (C) and slower semi-rapid adjustments involving the land surface and vegetation that further modify atmospheric circulation patterns (D). As the oceans respond to radiative forcing, longer timescale feedbacks, involving the atmosphere, land, and oceans, alter the surface and atmospheric energy balance, driving increased global evaporation and precipitation (E). This slow response of precipitation to global mean surface temperature is quantified as the hydrological sensitivity, $\eta$, while the total precipitation response, including initial fast adjustments, is termed the apparent hydrological sensitivity, $\eta_{a}(\mathrm{~F})$. The precipitation response over land and ocean develops over time (G-J) with land hydrological sensitivity tending to be suppressed relative to the global mean.

concentrations of $\mathrm{CO}_{2}$ are instantaneously quadrupled (Fig. 3; simulations listed in Table 1). Global mean precipitation, relative to a preindustrial control, increases linearly with global mean temperature (Fig. 3, black dots and line of best fit) at the rate of 2.7 and $2.3 \% / \mathrm{K}$ in the two $4 \times \mathrm{CO}_{2}$ simulations ( $\eta$, Fig. $2 \mathrm{~F}$ ), consistent with previous estimates of $2.1-3.1 \% / \mathrm{K}^{39,40}$ This rate of increase can be understood in terms of radiative transfer that links increased radiative cooling to thermal deepening of the troposphere, ${ }^{351}$ while idealized modeling has recently uncovered the role of surface evaporation as a limiting factor for the atmospheric warming that also determines the magnitude of $\eta{ }^{41}$ Climate feedbacks also modulate the magnitude of $\eta,{ }^{30}$ and model simulations may underestimate $\eta$ due to deficiencies in the representation of feedbacks from low-altitude cloud, ${ }^{42}$ which are linked with hydrological sensitivity through their dependence on temperature lapse rate responses. ${ }^{41}$ Uncertainty in the sensitivity of shortwave absorption by atmospheric water vapor to temperature can explain much of the range in simulated hydrological sensitivity ${ }^{43}$ although longwave feedbacks also contribute. ${ }^{44}$ Consistency in hydrological sensitivity does, however, disguise contrasting regional responses that are particularly dependent on forcing agent. ${ }^{40,44}$

The apparent hydrological sensitivity $\left(\eta_{a}\right)$ is reduced relative to hydrological sensitivity $(\eta)$ by greenhouse gases and absorbing aerosols, which alter the atmospheric radiation balance, driving rapid adjustments in global precipitation. A rapid adjustment in response to the quadrupling of atmospheric $\mathrm{CO}_{2}$ concentration is illustrated in Figure 3: following the black regression line back to the 


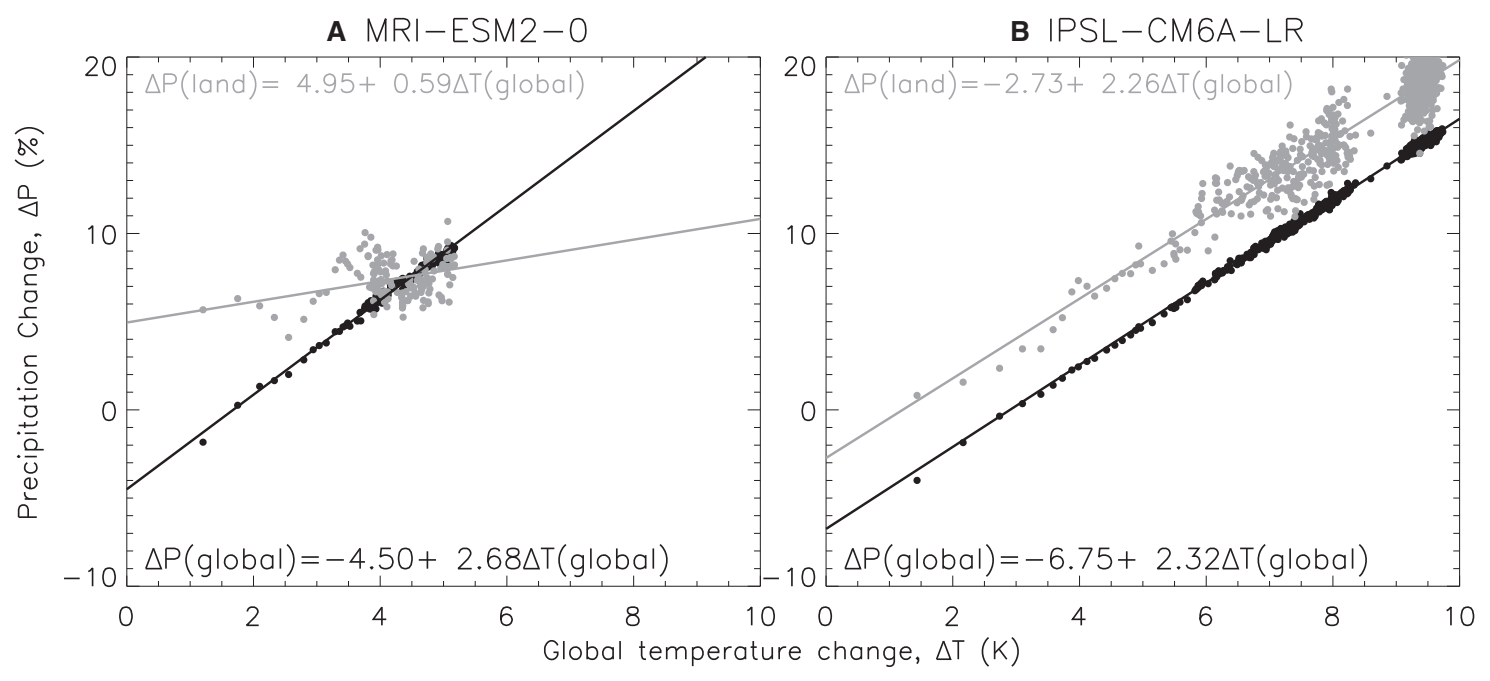

Figure 3. Precipitation changes for global mean (black) and land mean (gray) in response to global mean temperature changes for a $4 \times \mathrm{CO}_{2}$ experiment relative to a 30-year mean preindustrial control for (A) MRI-ESM2-0 150-year experiment and (B) IPSL-CM6A-LR 900-year experiment (showing the first 300 and last 300 years), where each dot represents 1 year of data.

$y$-axis implies a decrease in global precipitation before global temperatures have begun increasing in response to the elevated $\mathrm{CO}_{2}$ levels $(-4.5 \%$ and $-6.8 \%$ in the two simulations in Fig. 3). This reflects the rapid adjustments to the atmospheric heating influence of $\mathrm{CO}_{2}$ radiative forcing, most of which is transferred to the ocean through fast responses in atmospheric vertical motion and circulation. Rapid adjustment effects on precipitation are less certain than the slow responses to surface temperature. ${ }^{34,62}$ The rapid adjustments depend upon how each radiative forcing manifests throughout the atmosphere and surface and explains why the apparent hydrological sensitivity is lower than the hydrological sensitivity for $\mathrm{CO}_{2}$ forcing (Fig. 2F). Despite uncertainty in the fast precipitation response to radiative forcing, similar spatial patterns are simulated for greenhouse gas, solar, and absorbing aerosol radiative forcings. ${ }^{63,64}$

Climate drivers that primarily impact the surface rather than atmospheric energy budget initially produce only a small rapid reduction in precipitation. Examples include solar forcing and sulfate aerosol, which produce larger $\eta_{a}$ than drivers primarily modulating aspects of the atmospheric energy budget, such as greenhouse gases and absorbing aerosol. ${ }^{63,65-67}$ Thus, global precipitation appears more sensitive to radiative forcing from sulfate aerosols $\left(2.8 \pm 0.7 \% /{ }^{\circ} \mathrm{C}, \eta_{a} \sim \eta\right)$ than green- house gases $\left(1.4 \pm 0.5 \% /{ }^{\circ} \mathrm{C}, \eta_{a}<\eta\right)$, while the response to black carbon aerosol can be negative $\left(-3.5 \pm 5.0 \% /{ }^{\circ} \mathrm{C}, \eta_{a}<<\eta\right)$ due to strong atmospheric solar absorption. ${ }^{63}$ In four different climate models, the response to a complete removal of present day anthropogenic aerosol emissions was an increase in global mean precipitation $\left(\eta_{a}=1.6-\right.$ $5.5 \% /{ }^{\circ} \mathrm{C}$ ), mainly attributed to the removal of sulfate aerosol as opposed to other aerosol species. ${ }^{68} \eta_{a}$ also depends on the pattern of aerosol forcing. For example, increased Asian sulfates produce a larger global precipitation response than for comparable aerosol changes over Europe. ${ }^{69}$ The vertical profile of black carbon and ozone influences the magnitude of the fast global precipitation response, yet is more difficult to observe and simulate. ${ }^{70-72}$ The range of apparent hydrological sensitivity obtained from six simulations of the last glacial maximum and preindustrial period $\left(\eta_{a}=1.6-3.0 \% /{ }^{\circ} \mathrm{C}\right)$ is greater than for a $4 \times \mathrm{CO}_{2}$ experiment $\left(\eta_{a}=1.3-\right.$ $2.6 \% /{ }^{\circ} \mathrm{C}$ ) in which larger $\mathrm{CO}_{2}$ forcing suppresses precipitation response due to fast adjustments. ${ }^{73}$ However, thermodynamic constraints on evaporation and contrasting vegetation and land surface states also play a role. A range of fast precipitation adjustments to $\mathrm{CO}_{2}$ between models is attributed to the response of vegetation, leading to a repartitioning of surface latent and sensible heat fluxes. ${ }^{74}$ 
Table 1. List of observations and simulations with references

\begin{tabular}{|c|c|c|c|}
\hline Data set & Period (this study) & Resolution (lat, lon) & References \\
\hline HadCRUT4v4.6 & $1979-2018$ & $5^{\circ} \times 5^{\circ}$ & 45 \\
\hline HadCRUH & 1979-2003 & $5^{\circ} \times 5^{\circ}$ & 46 \\
\hline SSM/I & 1988-2019 & $0.25^{\circ} \times 0.25^{\circ}$ & 47 \\
\hline ERA5 & 1979-2019 & $0.25^{\circ} \times 0.25^{\circ}$ & 48 \\
\hline GPCPv2.3 & $1979-2018$ & $2.5^{\circ} \times 2.5^{\circ}$ & 49 \\
\hline AMIP6 simulations & 1980-2014 & & \\
\hline * Preindustrial control & 30 years & & \\
\hline$* 4 \times \mathrm{CO}_{2}$ & $>150$ years & & \\
\hline \# Historical & 1995-2014 & & \\
\hline \# SSP2-4.5 & $2081-2100$ & & \\
\hline BCC-CSM2-MR & & $1.125^{\circ} \times 1.125^{\circ}$ & 50 \\
\hline BCC-ESM1 & & $2.81^{\circ} \times 2.81^{\circ}$ & 50 \\
\hline CanESM5 $^{\#}$ & & $2.8^{\circ} \times 2.8^{\circ}$ & 51 \\
\hline CESM2 & & $0.94^{\circ} \times 1.25^{\circ}$ & 52 \\
\hline CNRM-CM6-1 & & $1.4^{\circ} \times 1.4^{\circ}$ & 53 \\
\hline CNRM-ESM2-1 & & $1.4^{\circ} \times 1.4^{\circ}$ & 54,55 \\
\hline GFDL-AM4 & & $1.0^{\circ} \times 1.25^{\circ}$ & 56 \\
\hline GISS-E2-1-G & & $2.0^{\circ} \times 2.5^{\circ}$ & 57 \\
\hline IPSL-CM6A-LR* & & $1.25^{\circ} \times 2.5^{\circ}$ & 58 \\
\hline MIROC6 & & $1.406^{\circ} \times 1.406^{\circ}$ & 59 \\
\hline MRI-ESM2-0 $*^{\#}$ & & $1.125^{\circ} \times 1.125^{\circ}$ & 60 \\
\hline UKESM1-0-LL & & $1.25^{\circ} \times 1.875^{\circ}$ & 61 \\
\hline
\end{tabular}

All models are used in the AMIP analysis in Figure 4, but only the CanESM5 and MRI-ESM2 historical and SSP2-4.5 experiments are used in Figure 5 (denoted by \#) and only the IPSL-CM6A-LR and MRI-ESM2 pre-industrial and $4 \times \mathrm{CO}_{2}$ experiments are used in Figure 3 (denoted by $*$ ).

Hydrological sensitivity is generally suppressed over land (Fig. 2E-I), with a large range $(\eta=0.8-$ $2.4 \% /{ }^{\circ} \mathrm{C}$ for $\mathrm{CO}_{2}$ doubling experiments) relative to the global mean $\left(\eta=2.3-2.7 \% /{ }^{\circ} \mathrm{C}\right)$ based on multiple simulations. ${ }^{40,44}$ This is partly explained by the greater warming over land than oceans. Since oceans supply much of the moisture to fuel precipitation over land, ${ }^{1,75}$ the slower ocean warming rate dictates that sufficient moisture cannot be supplied to maintain continental relative humidity, ${ }^{23}$ leading to a drying influence that is further amplified by land surface feedbacks. ${ }^{24} \mathrm{~A}$ weaker hydrological response over land is important for aridity changes and presents a challenge for attribution of continental precipitation changes to different climate forcings. ${ }^{40}$

The distinct response of water cycle responses over land is illustrated in Figure 3 (gray dots/lines). An implied rapid response in precipitation over land is more positive than the global rapid response in both model simulations. However, one model simulates an initial increase of $\sim 5 \%$ over land com- pared with a $4.5 \%$ decrease globally (Fig. 3A), while the other model simulates a decrease of $\sim 3 \%$ over land compared with a $7 \%$ initial decrease globally (Fig. 3B). The more positive initial precipitation response over land than globally can be explained by rapid land warming, in part from increased surface downwelling longwave radiation. This initially destabilizes the troposphere, strengthening vertical motion, moisture convergence, and precipitation over land in the short term. ${ }^{44,76,77}$ While the hydrological sensitivity over land is similar to the global response in one model (Fig. $3 \mathrm{~B}: \eta=2.3 \% /{ }^{\circ} \mathrm{C}$ ), the initial rapid increase in precipitation over land in the other simulation (Fig. 3A) is offset over time through a lower hydrological sensitivity over land $\left(\eta=0.6 \% /{ }^{\circ} \mathrm{C}\right)$ compared with the global response (Fig. 3A). Continental precipitation increases as a rapid response to $\mathrm{CO}_{2}$ have been counteracted by past increases in anthropogenic aerosols, which reflect and absorb solar radiation at the expense of surface heating and evaporation of surface moisture. ${ }^{78}$ The precise response depends upon the 


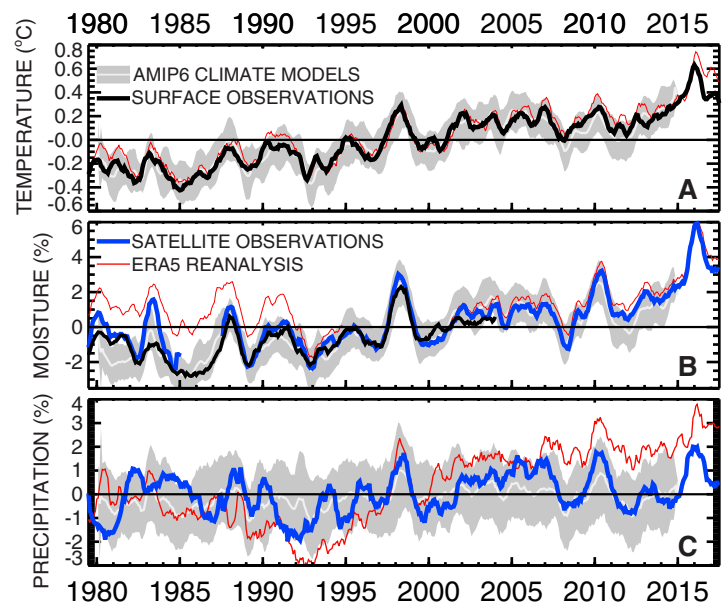

Figure 4. Observed and simulated deseasonalized global mean changes in (A) surface air temperature, (B) column integrated or near surface water vapor, and $(C)$ precipitation with 6-month smoothing and 1994-2000 reference period, including AMIP6 ensemble mean (white line) with shading representing \pm 1 standard deviation over 12 models (Table 1) and ERA5 reanalysis. ${ }^{48}$ Observed near surface temperature is from HadCRUTv4.6, ${ }^{45}$ column integrated water vapor is from SSM/I and SMMR satellite data ${ }^{47}$ over ice-free oceans and ERA5 elsewhere, and surface near surface-specific humidity is from HadCRUH $^{46}$ and observed precipitation from GPCP v2.3 ${ }^{49}$ and based on previous methods. ${ }^{21}$

aerosol type: sulfate aerosols primarily cool the surface, whereas black carbon aerosols absorb sunlight, heating the atmosphere, and this effect can dominate over the surface cooling effect. ${ }^{63}$ Recent observations suggest the absorption effects are important in explaining decreases in surface absorbed sunlight that reverse, first in Europe then China, in concert with action to reduce air pollution. ${ }^{79}$ Although aerosol cooling effects have opposed rapid precipitation increases in response to direct $\mathrm{CO}_{2}$ radiative forcing, these counteracting aerosol effects are expected to diminish with future declining aerosol forcing. ${ }^{44,80,81}$

Advances in the physical understanding of global precipitation responses can be used to interpret the present day global water cycle changes. Global mean temperature and water vapor are closely coupled (Fig. 4A and B). The linear fit between monthly deseasonalized column integrated water vapor and temperature $(1988-2014)$ is $6.8 \pm 0.4 \% /{ }^{\circ} \mathrm{C}$ in the SSM/I satellite-based observations and $7.1 \pm$ $0.3 \% /{ }^{\circ} \mathrm{C}$ in an ensemble of 12 atmosphere-only CMIP6 simulations (AMIP6, which apply observed
SST and sea ice plus realistic radiative forcings; Table 1). This is close to that expected from thermodynamics, assuming small global changes in relative humidity, and is substantially larger than the precipitation sensitivity of $3.2 \pm 0.8 \% /{ }^{\circ} \mathrm{C}$ in GPCP observations and $2.0 \pm 0.2 \% /{ }^{\circ} \mathrm{C}$ in AMIP6 simulations. These are within the range of $\eta$ from coupled simulations ${ }^{39,40}$ but are not directly comparable since interannual variability depends on cloud feedbacks specific to ENSO-related changes. ${ }^{82}$ Also shown are the ERA5 reanalysis estimates which, for temperature, show broad consistency with the other data sets. However, the ERA5 depiction of a decrease in water vapor during the early 1990s and larger trends and variability in global precipitation (Fig. 4B and C) are spurious based on the analysis of an earlier reanalysis version, ${ }^{21}$ underlining that global-scale water cycle trends in reanalysis products are not realistic.

Longer term trends are more relevant for expected climate change response, yet are limited by the observing system. Global mean warming of 0.15 $\pm 0.01{ }^{\circ} \mathrm{C} /$ decade and $1.0 \pm 0.1 \% /$ decade increases in moisture in the observations and AMIP6 simulations (1988-2014) imply a water vapor response of $6.7 \pm 0.3 \% /{ }^{\circ} \mathrm{C}$, very close to thermodynamic expectations. Corresponding precipitation trends are not significant at the $95 \%$ confidence level in the observations $(0.3 \pm 0.2 \% /$ decade $)$ and AMIP6 simulations $(0.14 \pm 0.06 \% /$ decade $)$, though they are consistent with the role of fast adjustments suppressing hydrological sensitivity in the near term. ${ }^{21,83}$ The implied apparent hydrological sensitivity $\left(\eta_{a}\right)$ is 2.0 $\pm 0.5 \% /{ }^{\circ} \mathrm{C}$ in the observations and $0.9 \pm 0.2 /{ }^{\circ} \mathrm{C}$ in the simulations. Cooling effects of anthropogenic aerosol and rapid adjustments to increases in greenhouse gases and absorbing aerosol reduce global mean precipitation, offsetting increases related to the warming climate. Multidecadal trends in global precipitation for the satellite era are, therefore, expected to be small and difficult to confirm due to observational uncertainty, ${ }^{21}$ and changes in sensible heat flux become significant in determining the precise global hydrological response. ${ }^{83}$ The warming influence of continued rises in $\mathrm{CO}_{2}$ concentration, compounded by declining aerosol cooling, is expected to accelerate increases in global precipitation and its extremes as the slow temperaturerelated responses dominate over rapid atmospheric adjustments to direct radiative forcing effects as 
transient climate change progresses. ${ }^{21,66,67,83-85}$ The observational record in Figure 4 is consistent with physical understanding that global mean precipitation increases more slowly than water vapor content per degree of warming. This has important implications since it determines an increase in water vapor lifetime ${ }^{22}$ and altered precipitation characteristics in terms of regional and seasonal duration, frequency, and intensity. ${ }^{86}$

\section{Thermodynamic constraints on regional precipitation minus evaporation patterns}

An important implication of increased atmospheric water vapor with warming (Fig. 4B) is a corresponding intensification of horizontal moisture transport that drives an amplification of existing precipitation minus evaporation (P-E) patterns (Fig. 5). At the regional scale, positive $\mathrm{P}-\mathrm{E}$ determines fresh water flux from the atmosphere to the surface, while negative P-E signifies a net flux of fresh water into the atmosphere. Atmospheric moisture balance is
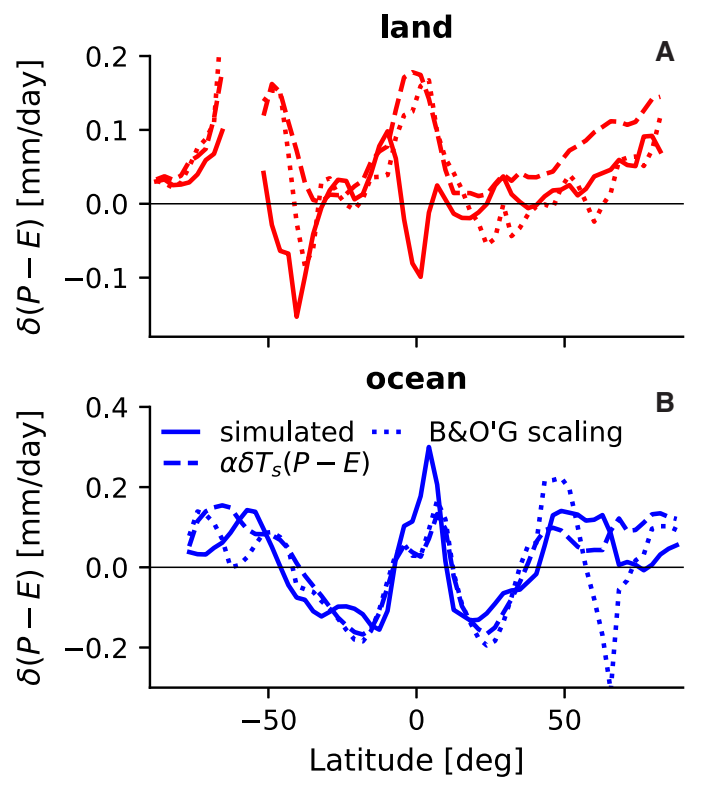

Figure 5. Zonally averaged changes in precipitation minus evaporation $\delta(\mathrm{P}-\mathrm{E})$ over (A) land and (B) ocean between the historical (1995-2014) and SSP2-4.5 (2081-2100) simulations (smoothed in latitude using a three-point moving-average filter). The solid lines indicate the simulated changes, which are averages between the CanESM5 and MRI-ESM2-0 models. Dashed lines are a simple thermodynamic scaling, $\alpha \delta \mathrm{T}_{\mathrm{s}}(\mathrm{P}-\mathrm{E})$, and dotted lines show an extended scaling $\left(\alpha \approx 0.07 \mathrm{~K}^{-1}\right.$ and $\delta$ Ts is the change in time-mean local surface air temperature ${ }^{87}$ ). achieved primarily by horizontal moisture transport from net evaporative ocean regions into wet convergence zones. At the global scale over the land surface, $\mathrm{P}-\mathrm{E}$ is positive and approximately balanced by runoff and storage, while over the ocean $\mathrm{P}-\mathrm{E}$ is negative and approximately balanced by runoff from the land (Fig. 1B), with both factors influencing regional salinity.

A projected amplification of $\mathrm{P}-\mathrm{E}$ zonal mean patterns over the oceans is explained by the thermodynamic scaling of present day simulated $\mathrm{P}-\mathrm{E}$ (solid and dashed lines in Fig. 5B). This amplification of zonal mean $\mathrm{P}-\mathrm{E}$ is corroborated by an observed "fresh get fresher, salty get saltier" salinity response to warming. ${ }^{31,88,89}$ This amplification is moderated by proportionally larger evaporation increases over the subtropical oceans relative to the equatorial convergence zones and weakening of the tropical circulation..$^{90}$ Suppressed evaporation increases over low latitudes $\left(\sim 1 \% /{ }^{\circ} \mathrm{C}\right)$ are partly explained by rapid adjustments to $\mathrm{CO}_{2}$ increases and uptake of heat by the ocean compared with high latitudes. ${ }^{32}$ At higher latitudes, evaporation is further increased by the expansion of open water area as sea and lake ice melts with warming. ${ }^{91-94}$ However, ocean stratification due to heating of the upper layers from radiative forcing is identified as a mechanism for amplifying the salinity patterns beyond the responses driven by water cycle changes alone. ${ }^{95}$ Amplified P-E patterns are additionally reduced by atmospheric and ocean circulation changes that alter the locations of the wettest and, therefore, freshest ocean regions. Spatial shifts in atmospheric circulation are thus expected to modify thermodynamic responses locally. This is consistent with paleoclimate evidence showing that mean changes are roughly in agreement with thermodynamic scaling, ${ }^{73}$ while regional changes are dominated by dynamics. ${ }^{96-99}$ However, ice sheet responses also contribute to regional water cycle change over paleoclimate timescales. ${ }^{100-102}$

Over land, evaporation is regulated by energy fluxes over wet regions, with atmospheric vapor pressure and aerodynamics playing an important role, but for drier regions evaporation is limited by surface water availability. ${ }^{31,103}$ Changes in P-E over drier continental regions are consequently dominated by precipitation changes ${ }^{31}$ that are strongly determined by alteration in atmospheric circulation. Projected changes in $\mathrm{P}-\mathrm{E}$ patterns cannot be 
simply interpreted as a "wet gets wetter, dry gets drier" response. . $^{31,87,90,103,104}$ In a simplistic sense, ocean regions experiencing decreasing $\mathrm{P}-\mathrm{E}$ cannot meaningfully be described as "dry" 1 , and "dryness" or aridity over land is influenced by potential evaporation as well as precipitation. ${ }^{31,104,105}$ However, a more fundamental objection to "dry gets drier" over land is that $\mathrm{P}-\mathrm{E}$ is generally positive and balanced by river discharge over multiannual timescales (Fig. 1B), so increased moisture fluxes imply increased P-E with warming. ${ }^{31,87,103}$ It is, however, recognized that $\mathrm{P}-\mathrm{E}$ may be negative during the tropical dry season or extended dry spells, ${ }^{106}$ as ground water is lost to a "more thirsty" atmosphere due to greater evaporative demand ${ }^{104,105,107}$ and exported remotely. Thus, contrasting water cycle responses are expected for wet and dry periods at the seasonal or subseasonal timescale.

Decreases in soil moisture over many subtropical land regions are an expected response to a warming climate. ${ }^{20}$ Decreases in P-E over land are explained by reductions in relative humidity driven by increased land-ocean warming contrast and spatial gradients in temperature and humidity. ${ }^{87,108,109} \mathrm{~A}$ simple scaling accounting for these effects captures more closely the simulated responses over subtropical and Northern Hemisphere land (Fig. 5A). Drying over land is further amplified by vegetation responses ${ }^{24,108}$ and drives a reduction in moisture recycling. ${ }^{75}$ The control of soil moisture on evapotranspiration determines feedbacks onto surface climate, which vary across simulations ${ }^{110}$ and can cause delayed responses over multiple seasons. ${ }^{111}$

The response of vegetation to climate change and increased atmospheric $\mathrm{CO}_{2}$ concentrations also determines regional $\mathrm{P}-\mathrm{E}$, as well as aridity. Depending on their responses, plants may either amplify ${ }^{112}$ or ameliorate ${ }^{113}$ warming impacts on drought at the surface. Plant water use efficiency is determined by the ratio of photosynthesis to transpiration, which in turn is determined by stomatal conductance and vapor pressure deficit. Increased water use efficiency by plants is driven by enhanced photosynthesis and stomatal closure in response to higher $\mathrm{CO}_{2}$ levels. This can reduce evaporation from vegetated surfaces and exacerbate declining continental relative humidity and precipitation while limiting runoff increases and drying of soils at the root zone. ${ }^{12,13,110,113-119}$ However, increased plant growth in direct response to elevated $\mathrm{CO}_{2}$ concentrations that also drives greater tolerance to aridity can counteract increased water use efficiency, thereby offsetting the atmospheric drying, runoff increases, and soil drying effects ${ }^{12,13,38,114-116,120,121}$ Plant physiological responses thereby represent an uncertain component of semi-rapid adjustments to $\mathrm{CO}_{2}$ forcing (Fig. 2D).

Human activities also directly alter P-E over land. Intensive irrigation increases evapotranspiration and atmospheric water vapor locally. Although increased irrigation efficiency may ensure more water is available to crops, the corresponding reduction in runoff and subsurface recharge may exacerbate hydrologic drought deficits. ${ }^{122}$ Land use change, including deforestation and urbanization, can further alter regional $\mathrm{P}$ and $\mathrm{E}$ through changes in the surface energy and water balance. Direct human interference with the land surface combined with complex surface feedbacks thereby complicates the expected regional water cycle responses over land. Therefore, while increased moisture transport into wet parts of the atmospheric circulation will amplify P-E patterns globally, the interactions of geography, atmospheric circulation, human activities, and feedbacks involving vegetation and soil moisture lead to a complex regional response over land. However, multiple lines of evidence indicate that the contrast between wet and dry meteorological regimes, seasons, and events will amplify as moisture fluxes increase in a warming climate. ${ }^{123-133}$

\section{Large-scale responses in atmospheric circulation patterns}

Changes in the large-scale atmospheric circulation dominate regional water cycle changes, yet are not as well understood as changes in thermodynamics. Expected large-scale responses in a warming climate are a weakening and broadening of tropical circulation with poleward migration of tropical dry zones and mid-latitude jets. ${ }^{20}$ Land use change and large-scale irrigation also drive local and remote responses in atmospheric circulation and precipitation by altering the surface energy and moisture balance. ${ }^{134-138}$ Atmospheric circulation responds rapidly to radiative forcing ${ }^{40,63,77,139-142}$ and dominates the spatial pattern of precipitation change in response to different drivers. ${ }^{62,77,139,143}$ Radiative forcings with heterogeneous spatial patterns, 
such as ozone and aerosol (particularly related to cloud interactions), drive atmospheric circulation changes through spatially and vertically uneven heating and cooling. ${ }^{144-146}$ These responses are uncertain for aerosol forcing, particularly for black carbon. ${ }^{147}$ Robust changes in atmospheric circulation are also driven by slower, evolving patterns of warming, including land-ocean contrasts, ${ }^{62,143,148}$ that are sensitive to model biases. ${ }^{149}$

A reduced atmospheric overturning circulation is required to reconcile low-level water vapor increases of $\sim 7 \% /{ }^{\circ} \mathrm{C}$ with smaller global precipitation responses of $2-3 \% /{ }^{\circ} \mathrm{C}$, a consequence of thermodynamic and energy budget constraints. ${ }^{20}$ The slowdown can occur in both the Hadley and Walker circulations, but in most climate models occurs preferentially in the Walker circulation. Paleoclimate simulations and observations support a Walker circulation weakening with warming. ${ }^{150}$ However, internal climate variability can temporarily strengthen the Walker circulation over decadal timescales. ${ }^{151,152}$ Although a weaker Walker circulation is associated with El Niño, the associated regional water cycle impacts are not necessarily relevant for climate change responses since the mechanisms driving weakening differ. ${ }^{9}$

There is also a direct link between $\mathrm{CO}_{2}$ increases and atmospheric circulation response: ${ }^{153-155}$ a rapid $3-4 \%$ slowdown of the large-scale tropical circulation in response to instantaneous quadrupling of $\mathrm{CO}_{2}{ }^{153}$ is dominated by reduced tropospheric radiative cooling in subtropical ocean subsidence regions. ${ }^{62,77,156}$ Subsequent surface warming contributes to a slowdown in circulation, the magnitude of which is estimated to reach $12 \%$ for a uniform $4{ }^{\circ} \mathrm{C}$ SST increase, driven by the enhancement of atmospheric static stability through thermodynamic decreases in temperature lapse rate $e^{153}$ and an increase in tropopause height. ${ }^{20,157}$ The Hadley cell response is mainly manifest as a widening or poleward shift, partly driven by changes in subtropical baroclinicity and an increase in subtropical static stability. ${ }^{158}$

A fundamental component of the Hadley circulation is the Intertropical Convergence Zone (ITCZ), the position, width, and strength of which determine the location and seasonality of the tropical rain belt. Cross-equatorial energy transport is important in determining the mean ITCZ position and both of these attributes display systematic biases in climate model simulations ${ }^{159-164}$ that can also influence tropical precipitation response to warming. ${ }^{165-167}$ Reduced surface sunlight due to aerosol scattering and absorption that preferentially affects the Northern Hemisphere partially explains a southward shift of the $\mathrm{NH}$ tropical edge from the 1950 s to the $1980 s^{168,169}$ and the severe drought in the Sahel that peaked in the mid-1980s. ${ }^{170,171}$ Although changes in hemispheric energy imbalance drive relatively small $\left(<1^{\circ}\right.$ latitude, multidecadal $)$ shifts in the zonally averaged ITCZ position based on observationally constrained simulations, ${ }^{172,173}$ short-term (1-2 years) responses to volcanic eruptions and internal variability can produce more rapid changes. ${ }^{174}$ Large shifts in the ITCZ $\left(>1^{\circ}\right.$ latitude, decades timescale) and regional monsoons are possible following a potential substantial slowdown or collapse of the Atlantic meridional overturning ocean circulation. ${ }^{175,176}$

Although a dynamical understanding of changes in ITCZ width and strength currently lags understanding of the controls on ITCZ position, energetic and dynamic theories have been developed. ${ }^{177-180}$ Weakening circulation with warming (diagnosed as upward mass transport within the global ITCZ divided by its area) results from a complex interplay between strengthened upward motion in the ITCZ core and weakened updrafts at the edges of the ITCZ. ${ }^{161,181}$ This leads to a drying tendency on the equatorward edges of the ITCZ ${ }^{177}$ and a moistening tendency in the ITCZ core: stronger ascent in the ITCZ core amplifies the "wet get wetter" response, while reduced moisture inflow near the ITCZ edges reduces the "wet gets wetter" response relative to the thermodynamic increase in moisture transport. Overall, ITCZ responses have been linked with hemispheric asymmetry in radiative forcing from greenhouse gases and aerosols, ${ }^{168,182,183}$ feedbacks involving clouds, ${ }^{184-186}$ and vertical energy stratification. ${ }^{179,187}$ Changes in the regional tropical rain belt are larger than for the global ITCZ and involve more complex dynamical mechanisms, ${ }^{188,189}$ including monsoons.

Monsoon systems represent an integral component of the seasonal shifts in the tropical rain belt that affect billions of people through the supply of fresh water for agriculture. Onset, retreat, and subseasonal characteristics of monsoons are determined by a complex balance between net energy input by radiative and latent heat fluxes 
and the export of moist static energy. This energy export is determined by contrasting surface heat capacity between ocean and land and modified through changes in atmospheric dynamics, tropical tropospheric stability, and land surface properties. ${ }^{99,160,190}$ Thermodynamic intensification of moisture transport increases the intensity and area of monsoon rainfall, but this is offset by a weakening tropical circulation. ${ }^{191,192}$

Monsoon systems are sensitive to spatially varying radiative forcing relating to anthropogenic aerosol $^{168,171,193,194}$ but also greenhouse gases ${ }^{183}$ and changes in SST patterns ${ }^{195,196}$ that play a strong role by altering cross-equatorial energy transports and land-ocean temperature contrasts. Aerosols affect the monsoon by altering hemispheric temperature gradients and cross-equatorial energy transports but also drive more local changes through altering land-ocean contrasts and changing moisture flux that depend on whether absorbing or scattering aerosol dominate. ${ }^{197}$ Reduced surface sunlight due to aerosol increases over land and the oceanic response to reduced cross-equatorial flow can amplify the northward gradient of SST, thereby weakening the Indian monsoon. ${ }^{148}$ Although there has been disagreement between paleoclimate and modern observations, physical theory, and numerical simulations of monsoonal changes, many of these discrepancies have been explained by considering regional aspects, such as zonal asymmetries in the circulation, land/ocean differences in surface fluxes, and the character of convective systems. $^{98,99,190,198,199}$

Poleward expansion of the tropical belt is expected to drive a corresponding shift in midlatitude storm tracks, yet driving mechanisms differ between hemispheres. Greenhouse gas forcing drives a stronger poleward expansion in the Southern Hemisphere than the Northern Hemisphere. In addition, tropospheric ozone and anthropogenic aerosol forcing contribute to the Northern Hemisphere changes, while an amplification of the Southern Hemisphere response by stratospheric ozone depletion will not apply as ozone levels recover. ${ }^{200-203} \mathrm{~A}$ thermal gradient between the polar and lower latitude regions that decreases at low altitudes and increases in the upper troposphere as the planet warms is consistent with a strengthening of the winter jet stream in both hemispheres. However, the precise mechanisms are complex $^{204}$ and the influence of amplified Arctic warming on mid-latitude regional water cycles is not well understood based on simple physical grounds due to the large number of competing physical processes. ${ }^{205-210}$ Weakening of the Northern Hemisphere summer jet stream is thought to potentially amplify wet and dry extremes through increased persistence of weather types ${ }^{211}$ and was linked to reduced precipitation in mid-latitudes based on an early Holocene paleoclimate record..$^{212}$ However, recent analysis of observations and coupled climate simulations show little influence of Arctic warming amplification on mid-latitude climate. ${ }^{213,214}$ Regardless of this uncertainty, thermodynamic increases in moisture and convergence within extratropical cyclones is a robust driver of precipitation increases within mid-high latitude wet events, with implications for more severe flooding.

\section{Changes in characteristics of precipitation and hydrology}

Heavy precipitation is expected to become more intense as the planet continues to warm..$^{215-217}$ Increases in low-altitude moisture of around $7 \% /{ }^{\circ} \mathrm{C}$ provide a robust baseline expectation for a similar rate of intensification in extreme precipitation, but this is modified by less certain microphysical and dynamical responses ${ }^{215,218,219}$ that are space and timescale dependent. ${ }^{86}$ The response of streamflow and flooding to changing rainfall characteristics is complex (Fig. 6) and there is not a strong relationship between flood hazard and precipitation at the monthly scale. ${ }^{220,221}$ The likelihood of flooding is influenced by snowmelt and antecedent soil moisture $e^{222-224}$ that also depend on time and space scales, as well as the nature of the land surface. These complex drivers explain regionally dependent increases and decreases in flooding observed over Europe. ${ }^{25,226}$ Expected drivers of streamflow and flooding are also dependent on direct human intervention, such as river catchment management that can include mismanagement leading to infrastructure failure (e.g., reservoirs), as well as detrimental changes in catchment drainage properties or land stability (e.g., mudslides).

Over mid-latitude regions, the amount and intensity of rainfall within extratropical storms is expected to increase with atmospheric moisture. This is particularly evident for atmospheric rivers: long, narrow bands of intense horizontal moisture 


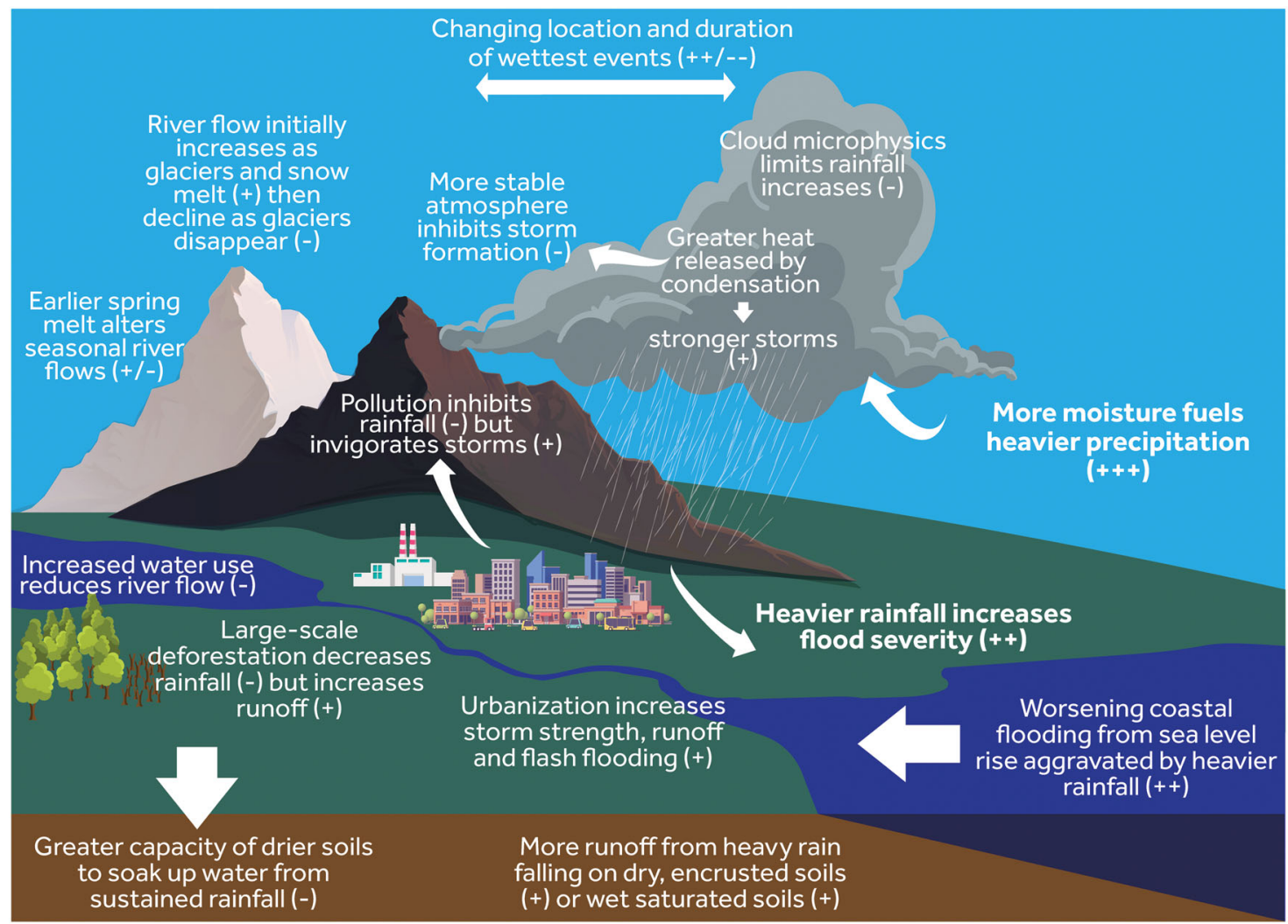

Figure 6. Schematic illustrating factors important in determining changes in heavy precipitation and flooding.

transport within the warm sector of extratropical cyclones $^{227,228}$ that are linked with flooding, ${ }^{229-232}$ changes in terrestrial water storage, ${ }^{233}$ and the mass balance of glaciers and snowpack. ${ }^{234-237}$ Assuming minor changes in dynamical characteristics, it is expected that increased atmospheric moisture flux will intensify atmospheric river events. ${ }^{238-241}$ However, changes in location, orientation, and dynamical aspects relating to wind speed will dominate responses in some regions.

Warming is expected to decrease snowfall globally but could drive increases in intensity regionally, particularly in high latitude winter, since heavy snow tends to occur close to the freezing point, ${ }^{242,243}$ which will migrate poleward, in altitude and seasonally. A shorter snow season can be offset by increased snowfall relating to thermodynamic increases in atmospheric moisture. ${ }^{244}$ Warming is expected to reduce rain-on-snow melt events at lower altitudes due to declining snow cover but increase these events at higher altitudes as snow is replaced by rain. ${ }^{245,246}$ Early but less rapid snowmelt is expected from the reduced available radiative energy earlier in the season. ${ }^{247}$ Earlier and more extensive winter and spring snowmelt ${ }^{248}$ has been further linked with declining summer and autumn runoff in snow-dominated river basins of mid to high latitudes of the Northern Hemisphere. ${ }^{25,249}$ Increased glacier melt and precipitation are expected to contribute to increasing lake levels, as identified for the inner Tibetan Plateau. ${ }^{250}$ In a warming climate, glacier runoff is initially expected to increase due to additional melt before decreasing in the longer term as glacier volume shrinks, with peak runoff already achieved for some smaller glaciers. ${ }^{251}$ Changes in the cryosphere thereby drive regional- and seasonal-dependent changes in flooding that may alter in magnitude and even sign over longer timescales.

Increased severity of flooding on larger, more slowly responding rivers is expected as precipitation increases during persistent wet events over 
a season. This can occur in mid-latitudes, where blocking patterns continually steer extratropical cyclones across large river catchments, with groundwater flooding also playing a role. ${ }^{211,252}$ Catastrophic floods recorded across Europe and Asia have been linked to persistent atmospheric circulation patterns. ${ }^{253-257}$ Increased atmospheric moisture will amplify the severity of these events when they occur, ${ }^{258}$ yet changes in occurrence of blocking patterns, stationary waves, and jet stream position depend on multiple drivers and so are not well understood. ${ }^{207}$ Arctic amplification reduces the low-level latitudinal temperature gradient, which implies a slower or less zonal jet stream and potentially longer duration wet or dry events. However, a stronger temperature gradient in the mid-latitude upper troposphere is expected as the topical upper troposphere warms and the highlatitude lower stratosphere cools. This potentially drives a stronger jet stream and shorter duration but more intense precipitation associated with the passage of extratropical cyclones, as was found to apply for $30-70^{\circ} \mathrm{N}$ in CMIP5 projections. ${ }^{259}$

A weakening tropical circulation is expected to reduce tropical cyclone system speed, thus amplifying thermodynamic intensification of rainfall, though observational evidence supporting this has been questioned. ${ }^{260-262}$ Flooding associated with storm systems can be exacerbated by an increased severity of coastal inundation due to sea level rise. ${ }^{263,264}$ Sensitivity experiments indicate that the most intense rainfall within tropical and extratropical cyclones can increase with warming above the Clausius-Clapeyron rate. ${ }^{265,266}$ There is also observational evidence, ${ }^{267-269}$ supported by simulations, ${ }^{270-272}$ that ingestion of aerosols into tropical cyclones can invigorate the peripheral rain bands and increase the overall area and precipitation of the storm. This occurs at the expense of air converging into the eyewall, thus may decrease the storm's maximum wind speed by up to one class in the Sapphire-Simpson scale. However, large-scale cooling from anthropogenic aerosol has been linked with a decreased frequency of tropical storms over the north Atlantic, which reversed at the end of the century as aerosol emissions declined. ${ }^{273}$

Increased seasonality in lower latitudes, with more intense wet seasons, ${ }^{106,124,129,130,274}$ will alter seasonal hydrology. Decreases in precursor soil moisture after more intense dry seasons may increase the timescale over which seasonal rainfall saturates soils and aquifers. Drying of soils can, therefore, reduce the probability of seasonal flooding, while saturated soils associated with more intense wet seasons can increase waterlogging (Fig. 6). Changes in seasonal flood timing in response to climate variability are found to be more sensitive than for rainfall-based metrics. The median change in flood timing over East Africa between El Niño and La Niña of 53 days $^{275}$ is substantially larger than implied from a rainfall-based estimates of 14 days. ${ }^{276}$

Increased land-ocean temperature gradients have been linked with more intense precipitation over the Sahel based on satellite data since the 1980s. ${ }^{277}$ Surface feedbacks, involving soil moisture and vegetation, are also expected to modify regional responses over land, ${ }^{24}$ including for active to break phase transition over India. ${ }^{278,279}$ The spatial variability in soil moisture has been linked with the timing and location of convective rainfall through altering the partitioning between latent and sensible heating. This has been demonstrated for the Sahel and Europe using satellite data and is not well represented by simulations. ${ }^{280-282}$ Changes in soil moisture and vegetation can, therefore, produce varying effects on rainfall location and intensity. ${ }^{283,284}$ Antecedent soil moisture conditions are an important modulator of flooding but less so for more severe flood events. ${ }^{224}$ Defoliation has also been identified as a short-term driver of the regional hydrological cycle with enhanced runoff following a destructive tropical cyclone. ${ }^{285}$ Increased plant water use efficiency in response to elevated $\mathrm{CO}_{2}$ concentrations is linked with decreased mean precipitation but increased heavy precipitation days over tropical regions (parts of the Andes, western Amazon, central Africa, and the Maritime Continent) based on modeling experiments. ${ }^{286}$ More efficient water use by plants can further cause increasing runoff responses to rainfall, particularly for extremes. ${ }^{13,287,288}$

Precipitation and streamflow are also affected directly by human activities, and water use can offset and even dominate responses to climate change regionally. ${ }^{289}$ Deforestation can drive increased streamflow as demonstrated by simulations and observations over the Amazon and East Africa, ${ }^{290-292}$ although this can be counterbalanced 
by decreases resulting from irrigation. ${ }^{293}$ Largescale forest clearance can also drive reductions in precipitation, which was found to apply for total Amazon deforestation ${ }^{294}$ but with a substantial range $(-38$ to $+5 \%)$ across 44 studies, ${ }^{295}$ with smaller reductions $(-2.3$ to $-1.3 \%)$ estimated from observed Amazon deforestation up to 2010. Smallscale deforestation can actually increase precipitation locally ${ }^{296}$ and alter storm locations. Altered thermodynamic and aerodynamic properties of the land surface from urbanization can affect precipitation through altered stability and turbulence ${ }^{297-299}$ and are further perturbed through the effect of aerosol pollution on cloud microphysics. ${ }^{300}$ Urbanization also tends to decrease permeability of the surface, leading to increased surface runoff, ${ }^{301}$ and enhanced urban heat island effects are also known to invigorate convection. ${ }^{299,302}$

Urban air pollution can invigorate warm base convective storms. The addition of aerosol particles that serve as cloud condensation nuclei (CCN) leads to clouds with more numerous smaller droplets, which are slower to coalesce into raindrops. Therefore, clouds in more polluted air masses need to grow deeper to initiate rain. ${ }^{303-305}$ In clouds with a warm base and depths extending to heights with subzero temperatures, rain suppression increases cloud water that can freeze into large ice hydrometeors and produce heavy rain rates. The added latent heat of freezing can further invigorate the clouds, ${ }^{306,308}$ but simulations indicate this heating may be compensated by changes in latent heat at different cloud altitudes. ${ }^{307}$ An additional invigoration mechanism, which works mainly in convective tropical clouds with strong coalescence and warm rain, is caused by small aerosol particles $(<0.05$ $\mu \mathrm{m}$ ) that enhance the condensation efficiency of the vapor. ${ }^{313}$ These cloud invigoration mechanisms redistribute light rainfall from shallow clouds to heavy rainfall from deep clouds. The aerosol convective invigoration effect is nonmonotonic, where the invigoration reverses to weakening at aerosol optical depth greater than $\sim 0.3$, though the precise value is dependent on the environmental conditions. ${ }^{308-310}$ This is mainly caused by reduced surface solar heating due to aerosol effects that propels the convection but is also explained by suppression at the cloud edges, which begins to dominate at high aerosol loading. ${ }^{310}$ The magnitude of the ice-forming nuclei effects of aerosols is poorly known, but likely much smaller than their effects as CCN, except for snow enhancement in shallow orographic clouds. ${ }^{311}$ Light-absorbing aerosols, like the microphysical effects of CCN, can redistribute rain intensities from light to heavy. Absorbing aerosol radiative effects increase both instability and convective inhibition, which suppresses the small clouds and enhances the large rain cloud systems. ${ }^{312}$ When the instability is released, often triggered by topographical barriers, intense rainfall and flooding can occur. ${ }^{313,314}$ Such trends were found in India ${ }^{315}$ and eastern China during 1970-2010, and shown to be associated with the increasing amounts of black carbon aerosols there. ${ }^{316,317}$

Recent advances have been made in understanding the expected changes in subdaily rainfall intensity that can be particularly important in determining flash flooding. ${ }^{318}$ The intensity of convective storms is related to Convective Available Potential Energy, which is expected to increase thermodynamically with warming, ${ }^{319,320}$ although the heaviest rainfall is not necessarily associated with the most intense storms in terms of depth, based on satellite data. ${ }^{321}$ Intensification can exceed thermodynamic expectations since additional latent heating may invigorate individual storms ${ }^{322-328}$ (Fig. 6), and an increasing height of the tropopause with warming allows the establishment of larger systems ${ }^{329}$ that can amplify total storm precipitation. ${ }^{326}$ This is corroborated by observed scalings up to three times the rate expected from the Clausius-Clapeyron equation for multiple regions, ${ }^{329-332}$ albeit with low statistical certainty. ${ }^{333,334}$ The relevance of present-day relationships to climate change remains questionable, ${ }^{335,336}$ although is improved by considering scaling with dewpoint temperature, which reduces dependence on dynamical factors. ${ }^{329,337,338}$ Increased frequency of rainfall events above a fixed intensity threshold ${ }^{339}$ primarily reflects the less severe precipitation events intensifying above the threshold, so intensification of heavy rainfall in weather systems remains the dominant mechanism.

Intensification of subdaily rainfall is inhibited in regions and seasons where available moisture is limited, ${ }^{326}$ and simulations indicate that scaling can depend on time of day. ${ }^{340}$ However, a fixed threshold temperature above which precipitation is limited by moisture availability is not supported 
by recent modeling evidence. ${ }^{133,217,326}$ Enhanced latent heating of the atmosphere by more "juicy" storms can also suppress convection at larger scales due to atmospheric stabilization (Fig. 6), as demonstrated with high-resolution, idealized, and large ensemble modeling studies. ${ }^{325,328,341-343}$ Large eddy simulations demonstrate that stability controls precipitation intensity, moisture convergence governs storm area fraction, while relative humidity determines both intensity and area fraction. ${ }^{341}$ Atmospheric stability is also increased by the direct radiative heating effect from higher concentrations of $\mathrm{CO}_{2}{ }^{344}$ and aerosol through local effects on the atmospheric energy budget and cloud development. Intensification of short-duration intense rainfall is expected to increase the severity and frequency of flash flooding, ${ }^{345,346}$ and more intense but less frequent storms $^{328}$ are also expected to favor runoff and flash flooding at the expense of recharge since a drier surface reduces percolation from intense rain. ${ }^{347,348}$

Recent modeling evidence shows that increases in convective precipitation extremes are limited by microphysical processes involving droplet/ice fall speeds. ${ }^{345,349}$ Although instantaneous precipitation extremes are sensitive to microphysical processes, daily extremes are determined more by the degree of convective aggregation in one comparison of idealized model simulations. ${ }^{350}$ Thus, regional processes and their impact on dynamical responses are crucial in determining how regional precipitation intensity and hydrology respond to climate change (Fig. 6). Thermodynamic factors are, however, crucial in determining an intensification of heavy rainfall and associated flooding when extreme events occur.

\section{Conclusions}

Based on the physical understanding of thermodynamic processes, corroborated by observations and comprehensive simulations, the global water cycle is expected to intensify with warming in terms of moisture fluxes within the atmosphere and exchanges with the land and ocean surface. This intensification will be offset by a weakening tropical circulation in response to changes in the global energy balance and regional temperature gradients. It is well understood that thermodynamic increases in low-altitude water vapor of about $7 \% /{ }^{\circ} \mathrm{C}$ are larger than the $2-3 \% /{ }^{\circ} \mathrm{C}$ increases in global evap- oration and precipitation that are driven by Earth's evolving energy balance in response to warming. The slowing of atmospheric circulation is required to reconcile these contrasting responses that also imply an increased water vapor residence time. Combined with more intense fluxes of moisture, this is expected to manifest as a region- and seasondependent shift in the distribution of precipitation characteristics, such as intensity, frequency, and duration. Increases in aerosols offset some of the warming effects that drive the intensification of the hydrological cycle, but this depends on the mix of aerosol species and there are strong regional variations. Regionally, more intense moisture fluxes will drive an amplification of wet and dry seasons and weather events, with the possibility of increased duration or persistence driven by tropical circulation weakening. However, regional increases and decreases in precipitation or aridity are expected to be dominated by spatial shifts in atmospheric wind patterns in many regions that alter the location of the wettest and driest parts of the global circulation, yet are less certain than thermodynamic drivers. Local-scale effects are further modulated by land surface feedbacks and vegetation responses to rising concentrations of $\mathrm{CO}_{2}$, as well as direct human interference with the water cycle through water use and land use change.

Recent advances in refining how the water cycle is expected to respond to continued emissions of greenhouse gases and aerosol are as follows:

- Understanding of how global precipitation and evaporation increase as the planet warms has strengthened based on idealized modeling. Precipitation and atmospheric circulation respond rapidly to different radiative forcing agents but with moderate uncertainty. There is greater certainty in the global response to the slower evolving warming patterns.

- It is now recognized that cooling from sulfate aerosol and atmospheric heating due to rising concentrations of absorbing aerosol has suppressed global precipitation increases over recent decades. However, the dominating greenhouse gas warming influence is expected to drive substantial future global precipitation increases closer to the hydrological sensitivity of $2-3 \% /{ }^{\circ} \mathrm{C}$, with an additional, temporary 
acceleration of precipitation increases due to declining aerosol forcing.

- Hydrological sensitivity over land is suppressed relative to the global mean and this has been related to land-ocean warming contrast and surface feedbacks. However, simulated responses are uncertain and do not fully capture the observed magnitude of continental relative humidity decline.

- There is further evidence that amplification of precipitation minus evaporation patterns is robust over the ocean. Understanding of responses over land has been refined beyond an inaccurate "wet get wetter, dry get drier" response. Now recognized as important are regional thermodynamic responses and feedbacks and how aridity or dryness depends on which aspects of the atmosphere, soil, or vegetation are the primary focus.

- There is increasing evidence that the water cycle is intensifying with increased moisture fluxes driving heavier rainfall. Amplified fresh water transport and exchanges between the atmosphere and surface are intensifying wet and dry seasons or weather events.

- Although atmospheric circulation responses are less certain than thermodynamic drivers, evidence for a weaker Walker circulation in a warmer climate has expanded. There is, however, recognition that internal variability can lead to temporary strengthening over a decadal timescale.

- Thermodynamic amplification of monsoon intensity is offset by a weakening tropical circulation, but additional suppression of monsoon precipitation due to reduced solar heating from aerosols is expected to reverse as aerosol emissions decline.

- There have been advances in understanding how hemispheric asymmetries in radiative forcing impact the tropical rain belt, with Northern Hemisphere cooling from sulfate aerosol implicated in a southward shift in the ITCZ associated with the 1980s Sahel drought. Greenhouse gas forcing is now thought to have contributed to the recovery in Sahel rainfall through intensification of the Sahara heat low.

- Recent evidence indicates a limited role for Arctic amplification of warming and the rapid reduction in sea ice area in modifying mid- latitude weather patterns, including the frequency of persistent jet stream position that can favor flooding or drought.

- There is a growing appreciation for the role of vegetation and land surface feedbacks on water cycle responses. Understanding of the direct response of plants to elevated $\mathrm{CO}_{2}$ concentrations has also advanced. Reduced stomatal conductance increases water use efficiency, thereby reducing transpiration, atmospheric humidity, and local precipitation. This can limit drying of soils and increased streamflow induced by climate change. However, increased photosynthesis and plant growth is also capable of counteracting the effects of increased water use efficiency in some regions for species that are not subject to severe water limitation.

- The role of atmospheric rivers in determining regional water stores in the ground and as snow or ice, as well as extreme rainfall and flooding, is increasingly recognized.

- There is a greater appreciation of the seasonal complexity in water cycle changes as wet and dry periods intensify, but the timing and characteristics of wet seasons, melt events, and streamflow evolve over time.

- Nonlinear changes in streamflow over multidecadal timescales are expected in some regions as accelerated glacier melt is followed by declining glacier volume. This can result in a peak in river discharge that has already been passed in some catchments.

- There have been advances in understanding responses of subdaily precipitation, including the possibility of storm invigoration through enhanced latent heating within storms but convective inhibition operating at larger scales as heat release stabilizes the atmosphere. Responses are thereby dependent on time and space scale, though uncertainty remains in modeling storm systems and their aggregation.

- There have been some advances in identifying the role of aerosols in cloud development through initial suppression of precipitation but deepening of clouds that drive convective invigoration in tropical clouds. The observed shift of rain intensities from low to high can in some cases be related to the 
combined microphysical and radiative effects of aerosols, suppressing the small and shallow convective clouds and enhancing the large and deep clouds.

- The role of land-sea temperature gradients, surface feedbacks involving soil moisture and vegetation, as well as deforestation are important in determining the location and intensity convective storms, while questions remain as to their representation in models.

- There is not a simple relation between rainfall intensification and flooding, though evidence has strengthened that the most severe flooding situations will worsen, especially for smaller catchments and urban environments, and can compound increased coastal inundation from sea level rise.

- There is now a greater appreciation for the direct impact of human activity on the water cycle through extraction of water from the ground and river systems for irrigation and industrial or domestic use, as well as how land use change can alter the surface energy and water balances; for example, large-scale deforestation is linked with increased streamflow but also altered wind patterns and reduced precipitation and humidity locally.

\section{Acknowledgments}

R.P.A. is funded by the National Centre for Earth Observation and U.K. Natural Environment Research Council SMURPHS Grant (NE/N006054/1). H.J.F. is funded by the Wolfson Foundation and the Royal Society as a Royal Society Wolfson Research Merit Award holder (Grant WM140025). A.G.P. was supported by the Regional and Global Model Analysis (RGMA) component of the Earth and Environmental System Modeling Program of the U.S. Department of Energy's Office of Biological \& Environmental Research (BER) via National Science Foundation (NSF) IA 1844590 and the National Center for Atmospheric Research, which is a major facility sponsored by the NSF under Cooperative Agreement No. 1947282. We also appreciate additional input from P. Arias, R. Betts, P. Braconnot, R. Cerezo-Mota, R. Chadwick, A. Diedhiou, J. Gergis, D. Jiang, A. Khan, W. Pokam Mba, K. Raghavan, J. Renwick, R.
Taylor, J. Tierney and C. Wigernes. Data is available from the following sources: HadCRUT and HadCRUH, www.metoffice.gov.uk/hadobs; SSM/I, www.remss.com; SMMR, podaac.jpl.nasa.gov; GPCP, www.ncei.noaa.gov; ERA5, https://cds. climate.copernicus.eu; CMIP6, esgf-node.llnl.gov.

\section{Author contributions}

R.P.A. conducted the analysis and lead writing of the paper, M.B. produced Figure 5, and all authors contributed to the assessment of the literature and writing of the manuscript.

\section{Competing interests}

The authors declare no competing interests.

\section{References}

1. Gimeno, L., A. Stohl, R.M. Trigo, et al. 2012. Oceanic and terrestrial sources of continental precipitation. Rev. Geophys. 50: 1-41.

2. Haug, G.H., D. Günther, L.C. Peterson, et al. 2003. Climate and the collapse of Maya civilization. Science 299: 17311735 .

3. Buckley, B.M., K.J. Anchukaitis, D. Penny, et al. 2010. Climate as a contributing factor in the demise of Angkor, Cambodia. Proc. Natl. Acad. Sci. USA 107: 67486752.

4. Pederson, N., A.E. Hessl, N. Baatarbileg, et al. 2014. Pluvials, droughts, the Mongol Empire, and modern Mongolia. Proc. Natl. Acad. Sci. USA 111: 4375-4379.

5. Asoka, A., T. Gleeson, Y. Wada, et al. 2017. Relative contribution of monsoon precipitation and pumping to changes in groundwater storage in India. Nat. Geosci. 10: 109-117.

6. Li, J., S.-P. Xie, E.R. Cook, et al. 2019. Deciphering human contributions to Yellow River flow reductions and downstream drying using centuries-long tree ring records. Geophys. Res. Lett. 46: 898-905.

7. Abbott, B.W., K. Bishop, J.P. Zarnetske, et al. 2019. Human domination of the global water cycle absent from depictions and perceptions. Nat. Geosci. 12: 533-540.

8. Dagan, G., P. Stier \& D. Watson-Parris. 2019. Analysis of the atmospheric water budget for elucidating the spatial scale of precipitation changes under climate change. Geophys. Res. Lett. 46: 10504-10511.

9. Pendergrass, A.G. \& D.L. Hartmann. 2014. Two modes of change of the distribution of rain. J. Clim. 27: 8357-8371.

10. Kuo, C.C., T.Y. Gan \& M. Gizaw. 2015. Potential impact of climate change on intensity duration frequency curves of central Alberta. Clim. Change 130: 115-129.

11. Scheff, J. \& D.M.W. Frierson. 2014. Scaling potential evapotranspiration with greenhouse warming. J. Clim. 27: 15391558.

12. Milly, P.C.D. \& K.A. Dunne. 2016. Potential evapotranspiration and continental drying. Nat. Clim. Chang. 6: 946949. 
13. Lemordant, L., P. Gentine, A.S. Swann, et al. 2018. Critical impact of vegetation physiology on the continental hydrologic cycle in response to increasing $\mathrm{CO}_{2}$. Proc. Natl. Acad. Sci. USA 115: 4093-4098.

14. Trenberth, K.E., J.T. Fasullo \& J. Mackaro. 2011. Atmospheric moisture transports from ocean to land and global energy flows in reanalyses. J. Clim. 24: 4907-4924.

15. Rodell, M., H.K. Beaudoing, T.S. L'Ecuyer, et al. 2015. The observed state of the water cycle in the early twenty-first century. J. Clim. 28: 8289-8318.

16. Zhou, Y., A.H. Sawyer, C.H. David, et al. 2019. Fresh submarine groundwater discharge to the near-global coast. Geophys. Res. Lett. 46: 5855-5863.

17. Stephens, G.L., J. Li, M. Wild, et al. 2012. An update on Earth's energy balance in light of the latest global observations. Nat. Geosci. 5: 691-696.

18. Hartmann, D.L., A.M.G. Klein Tank, M. Rusticucci, et al. 2013. Observations: atmosphere and surface. In Climate Change 2013: The Physical Science Basis. Contribution of Working Group I to the Fifth Assessment Report of the Intergovernmental Panel on Climate Change. T.F. Stocker, D. Qin, G.-K. Plattner, et al., Eds.: 159-254. Cambridge, UK and New York, NY: Cambridge University Press.

19. Boucher, O., D. Randall, P. Artaxo, et al. 2013. Clouds and aerosols. In Climate Change 2013: The Physical Science Basis. Contribution of Working Group I to the Fifth Assessment Report of the Intergovernmental Panel on Climate Change. T.F. Stocker, D. Qin, G.-K. Plattner, et al., Eds.: 571-657. Cambridge, UK and New York, NY: Cambridge University Press.

20. Collins, M., R. Knutti, J. Arblaster, et al. 2013. Longterm climate change: projections, commitments and irreversibility. In Climate Change 2013: The Physical Science Basis. Contribution of Working Group I to the Fifth Assessment Report of the Intergovernmental Panel on Climate Change. T.F. Stocker, D. Qin, G.-K. Plattner, et al., Eds.: 1029-1136. Cambridge, UK and New York, NY: Cambridge University Press.

21. Allan, R.P., C. Liu, M. Zahn, et al. 2014. Physically consistent responses of the global atmospheric hydrological cycle in models and observations. Surv. Geophys. 35: 533-552.

22. Øivind, H., G. Myhre, B.H. Samset, et al. 2019. Water vapour adjustments and responses differ between climate drivers. Atmos. Chem. Phys. 19: 12887-12899.

23. Byrne, M.P. \& P.A. O'Gorman. 2018. Trends in continental temperature and humidity directly linked to ocean warming. Proc. Natl. Acad. Sci. USA 115: 4863-4868.

24. Berg, A., K. Findell, B. Lintner, et al. 2016. Landatmosphere feedbacks amplify aridity increase over land under global warming. Nat. Clim. Chang. 6: 869-874.

25. Dunn, R.J.H., K.M. Willett, A. Ciavarella, et al. 2017. Comparison of land surface humidity between observations and CMIP5 models. Earth Syst. Dyn. 8: 719-747.

26. Douville, H. \& M. Plazzotta. 2017. Midlatitude summer drying: an underestimated threat in CMIP5 models? Geophys. Res. Lett. 44: 9967-9975.

27. Vanniere, B., M.-E. Demory, P.L. Vidale, et al. 2019. Multimodel evaluation of the sensitivity of the global energy budget and hydrological cycle to resolution. Clim. Dyn. 52: 6817-6846.

28. Willett, K.M., R.J.H. Dunn, P.W. Thorne, et al. 2014. HadISDH land surface multi-variable humidity and temperature record for climate monitoring. Clim. Past 10: 1983-2006.

29. Pendergrass, A.G. \& D.L. Hartmann. 2014. The atmospheric energy constraint on global-mean precipitation change. J. Clim. 27: 757-768.

30. O'Gorman, P.A., R.P. Allan, M.P. Byrne, et al. 2012. Energetic constraints on precipitation under climate change. Surv. Geophys. 33: 585-608.

31. Roderick, M.L., F. Sun, W.H. Lim, et al. 2014. A general framework for understanding the response of the water cycle to global warming over land and ocean. Hydrol. Earth Syst. Sci. 18: 1575-1589.

32. Siler, N., G.H. Roe, K.C. Armour, et al. 2019. Revisiting the surface-energy-flux perspective on the sensitivity of global precipitation to climate change. Clim. Dyn. 52: 3983-3995.

33. Bala, G., K. Caldeira \& R. Nemani. 2010. Fast versus slow response in climate change: implications for the global hydrological cycle. Clim. Dyn. 35: 423-434.

34. Andrews, T., P.M. Forster, O. Boucher, et al. 2010. Precipitation, radiative forcing and global temperature change. Geophys. Res. Lett. 37. https://doi.org/10.1029/ 2010GL043991.

35. Cao, L., G. Bala \& K. Caldeira. 2012. Climate response to changes in atmospheric carbon dioxide and solar irradiance on the time scale of days to weeks. Environ. Res. Lett. $7: 34015$.

36. Sherwood, S.C., S. Bony, O. Boucher, et al. 2015. Adjustments in the forcing-feedback framework for understanding climate change. Bull. Am. Meteorol. Soc. 96: 217-228.

37. Dong, B., R.T. Sutton, E. Highwood, et al. 2014. The impacts of European and Asian anthropogenic sulfur dioxide emissions on Sahel rainfall. J. Clim. 27: 7000-7017.

38. Guerrieri, R., S. Belmecheri, S.V. Ollinger, et al. 2019. Disentangling the role of photosynthesis and stomatal conductance on rising forest water-use efficiency. Proc. Natl. Acad. Sci. USA 116: 16909-16914.

39. Fläschner, D., T. Mauritsen \& B. Stevens. 2016. Understanding the intermodel spread in global-mean hydrological sensitivity. J. Clim. 29: 801-817.

40. Samset, B.H., G. Myhre, P.M. Forster, et al. 2018. Weak hydrological sensitivity to temperature change over land, independent of climate forcing. npj Clim. Atmos. Sci. 1: 20173.

41. Webb, M.J., A.P. Lock \& F.H. Lambert. 2018. Interactions between hydrological sensitivity, radiative cooling, stability, and low-level cloud amount feedback. J. Clim. 31: 18331850.

42. Watanabe, M., Y. Kamae, H. Shiogama, et al. 2018. Low clouds link equilibrium climate sensitivity to hydrological sensitivity. Nat. Clim. Chang. https://doi.org/10.1038/ s41558-018-0272-0.

43. DeAngelis, A.M., X. Qu, M.D. Zelinka, et al. 2015. An observational radiative constraint on hydrologic cycle intensification. Nature 528: 249-253. 
44. Richardson, T.B., P. Forster, T. Andrews, et al. 2018. Drivers of precipitation change: an energetic understanding. $J$. Clim. 31: 9641-9657.

45. Morice, C.P., J.J. Kennedy, N.A. Rayner, et al. 2012. Quantifying uncertainties in global and regional temperature change using an ensemble of observational estimates: the HadCRUT4 data set. J. Geophys. Res. Atmos. 117. https: //doi.org/10.1029/2011JD017187.

46. Willett, K.M., P.D. Jones, N.P. Gillett, et al. 2008. Recent changes in surface humidity: development of the HadCRUH dataset. J. Clim. 21: 5364-5383.

47. Wentz, F.J., L. Ricciardulli, K. Hilburn, et al. 2007. How much more rain will global warming bring? Science 317: 233-235.

48. Copernicus Climate Change Service Climate Data Store (CDS). 2017. Copernicus Climate Change Service (C3S): ERA5: fifth generation of ECMWF atmospheric reanalyses of the global climate 2017. Accessed September 1, 2019. https://cds.climate.copernicus.eu/cdsapp\#!/home.

49. Adler, R.F., G. Gu, M. Sapiano, et al. 2017. Global precipitation: means, variations and trends during the satellite era (1979-2014). Surv. Geophys. 38: 679-699.

50. Wu, T., Y. Lu, Y. Fang, et al. 2019. The Beijing Climate Center Climate System Model (BCC-CSM): the main progress from CMIP5 to CMIP6. Geosci. Model Dev. 12: 1573-1600.

51. Swart, N.C., J.N.S. Cole, V.V. Kharin, et al. 2019. The Canadian Earth System Model version 5 (CanESM5.0.3). Geosci. Model Dev. 12: 4823-4873.

52. Gettelman, A., C. Hannay, J.T. Bacmeister, et al. 2019. High climate sensitivity in the Community Earth System Model version 2 (CESM2). Geophys. Res. Lett. 46: 8329-8337.

53. Voldoire, A., D. Saint-Martin, S. Sénési, et al. 2019. Evaluation of CMIP6 DECK experiments with CNRM-CM6-1. J. Adv. Model. Earth Syst. 11: 2177-2213.

54. Séférian, R., C. Delire, B. Decharme, et al. 2016. Development and evaluation of CNRM Earth system modelCNRM-ESM1. Geosci. Model Dev. 9: 1423-1453.

55. Séférian, R., P. Nabat, M. Michou, et al. 2019. Evaluation of CNRM Earth-System model, CNRM-ESM 2-1: role of Earth system processes in present-day and future climate. J. Adv. Model. Earth Syst. 11: 4182-4227.

56. Zhao, M., J.-C. Golaz, I.M. Held, et al. 2018. The GFDL global atmosphere and land model AM4.0/LM4.0:1. Simulation characteristics with prescribed SSTs. J. Adv. Model. Earth Syst. 10: 691-734.

57. Elsaesser, G.S., A.D. Del Genio, J.H. Jiang, et al. 2017. An improved convective ice parameterization for the NASA GISS global climate model and impacts on cloud ice simulation. J. Clim. 30: 317-336.

58. Boucher, O., J. Servonnat, A.L. Albright, et al. 2020. Presentation and evaluation of the IPSL-CM6A-LR climate model. J. Adv. Model. Earth Syst. In review.

59. Tatebe, H., T. Ogura, T. Nitta, et al. 2019. Description and basic evaluation of simulated mean state, internal variability, and climate sensitivity in MIROC6. Geosci. Model Dev. 12: 2727-2765.

60. Yukimoto, S., T. Koshiro, H. Kawai, et al. 2019. MRI MRIESM2.0 model output prepared for CMIP6 CMIP. https: //doi.org/10.22033/ESGF/CMIP6.621.
61. Kuhlbrodt, T., C.G. Jones, A. Sellar, et al. 2018. The lowresolution version of HadGEM3 GC3.1: development and evaluation for global climate. J. Adv. Model. Earth Syst. 10: 2865-2888.

62. Bony, S., G. Bellon, D. Klocke, et al. 2013. Robust direct effect of carbon dioxide on tropical circulation and regional precipitation. Nat. Geosci. 6: 447-451.

63. Samset, B.H., G. Myhre, P.M. Forster, et al. 2016. Fast and slow precipitation responses to individual climate forcers: a PDRMIP multimodel study. Geophys. Res. Lett. 43: 27822791.

64. Xie, S.-P., B. Lu \& B. Xiang. 2013. Similar spatial patterns of climate responses to aerosol and greenhouse gas changes. Nat. Geosci. 6: 828-832.

65. Liu, F., T. Zhao, B. Wang, et al. 2018. Different global precipitation responses to solar, volcanic, and greenhouse gas forcings. J. Geophys. Res. Atmos. 123: 4060-4072.

66. Salzmann, M. 2016. Global warming without global mean precipitation increase. Sci. Adv. 2: e1501572.

67. Lin, L., Z. Wang, Y. Xu, et al. 2018. Larger sensitivity of precipitation extremes to aerosol than greenhouse gas forcing in CMIP5 models. J. Geophys. Res. Atmos. 123: 8062-8073.

68. Samset, B.H., M. Sand, C.J. Smith, et al. 2018. Climate impacts from a removal of anthropogenic aerosol emissions. Geophys. Res. Lett. 45: 1020-1029.

69. Liu, L., D. Shawki, A. Voulgarakis, et al. 2018. A PDRMIP multimodel study on the impacts of regional aerosol forcings on global and regional precipitation. J. Clim. 31: 44294447.

70. MacIntosh, C.R., R.P. Allan, L.H. Baker, et al. 2016. Contrasting fast precipitation responses to tropospheric and stratospheric ozone forcing. Geophys. Res. Lett. 43: 12631271.

71. Stjern, C.W., B.H. Samset, G. Myhre, et al. 2017. Rapid adjustments cause weak surface temperature response to increased black carbon concentrations. J. Geophys. Res. Atmos. 122: 11,462-11,481.

72. Allen, R.J. \& W. Landuyt. 2014. The vertical distribution of black carbon in CMIP5 models: comparison to observations and the importance of convective transport. J. Geophys. Res. 119: 4808-4835.

73. Li, G., S.P. Harrison, P.J. Bartlein, et al. 2013. Precipitation scaling with temperature in warm and cold climates: an analysis of CMIP5 simulations. Geophys. Res. Lett. 40: 4018-4024.

74. DeAngelis, A.M., X. Qu \& A. Hall. 2016. Importance of vegetation processes for model spread in the fast precipitation response to $\mathrm{CO}_{2}$ forcing. Geophys. Res. Lett. 43: 12,55012,559 .

75. Findell, K.L., P.W. Keys, R.J. van der Ent, et al. 2019. Rising temperatures increase importance of oceanic evaporation as a source for continental precipitation. J. Clim. 32: 77137726.

76. Chadwick, R., P. Good, T. Andrews, et al. 2014. Surface warming patterns drive tropical rainfall pattern responses to $\mathrm{CO}_{2}$ forcing on all timescales. Geophys. Res. Lett. 41: 610-615.

77. Richardson, T.B., P.M. Forster, T. Andrews, et al. 2016. Understanding the rapid precipitation response to $\mathrm{CO}_{2}$ 
and aerosol forcing on a regional scale. J. Clim. 29: 583594.

78. Wild, M. 2012. Enlightening global dimming and brightening. Bull. Am. Meteorol. Soc. 93: 27-37.

79. Schwarz, M., D. Folini, S. Yang, et al. 2020. Changes in atmospheric shortwave absorption as important driver of dimming and brightening. Nat. Geosci. 13: 110-115.

80. Rotstayn, L.D., M.A. Collier \& J.-J. Luo. 2015. Effects of declining aerosols on projections of zonally averaged tropical precipitation. Environ. Res. Lett. 10: 044018.

81. Acosta Navarro, J.C., A.M.L. Ekman, F.S.R. Pausata, et al. 2017. Future response of temperature and precipitation to reduced aerosol emissions as compared with increased greenhouse gas concentrations. J. Clim. 30: 939-954.

82. Stephens, G.L., M.Z. Hakuba, M.J. Webb, et al. 2018. Regional intensification of the tropical hydrological cycle during ENSO. Geophys. Res. Lett. 45: 4361-4370.

83. Myhre, G., B.H. Samset, O. Hodnebrog, et al. 2018. Sensible heat has significantly affected the global hydrological cycle over the historical period. Nat. Commun. 9: 1922.

84. Shine, K.P., R.P. Allan, W.J. Collins, et al. 2015. Metrics for linking emissions of gases and aerosols to global precipitation changes. Earth Syst. Dyn. 6: 525-540.

85. Wilcox, L.J., Z. Liu, B.H. Samset, et al. 2020. Accelerated increases in global and Asian summer monsoon precipitation from future aerosol reductions. Atmos. Chem. Phys. https://doi.org/10.5194/acp-2019-1188.

86. Pendergrass, A.G. 2018. What precipitation is extreme? Science 360: 1072-1073.

87. Byrne, M.P. \& P.A. O'Gorman. 2015. The response of precipitation minus evapotranspiration to climate warming: why the "wet-get-wetter, dry-get-drier" scaling does not hold over land. J. Clim. 28: 8078-8092.

88. Durack, P. 2015. Ocean salinity and the global water cycle. Oceanography 28: 20-31.

89. Skliris, N., J.D. Zika, G. Nurser, et al. 2016. Global water cycle amplifying at less than the Clausius-Clapeyron rate. Sci. Rep. 6: 38752.

90. Chadwick, R., I. Boutle \& G. Martin. 2013. Spatial patterns of precipitation change in CMIP5: why the rich do not get richer in the tropics. J. Clim. 26: 3803-3822.

91. Sharma, S., K. Blagrave, C.M. O’Reilly, et al. 2019. Widespread loss of lake ice around the Northern Hemisphere in a warming world. Nat. Clim. Chang. 9: 227231.

92. Wang, W., X. Lee, W. Xiao, et al. 2018. Global lake evaporation accelerated by changes in surface energy allocation in a warmer climate. Nat. Geosci. 11: 410-414.

93. Bintanja, R. \& F.M. Selten. 2014. Future increases in Arctic precipitation linked to local evaporation and sea-ice retreat. Nature 509: 479-482.

94. Laîné, A., H. Nakamura, K. Nishii, et al. 2014. A diagnostic study of future evaporation changes projected in CMIP5 climate models. Clim. Dyn. 42: 2745-2761.

95. Zika, J.D., N. Skliris, A.T. Blaker, et al. 2018. Improved estimates of water cycle change from ocean salinity: the key role of ocean warming. Environ. Res. Lett. 13: 074036.

96. DiNezio, P.N. \& J.E. Tierney. 2013. The effect of sea level on glacial Indo-Pacific climate. Nat. Geosci. 6: 485-491.
97. Scheff, J., R. Seager, H. Liu, et al. 2017. Are glacials dry? Consequences for paleoclimatology and for greenhouse warming. J. Clim. https://doi.org/10.1175/JCLI-D16-0854.1.

98. Bhattacharya, T., J.E. Tierney \& P. DiNezio. 2017. Glacial reduction of the North American monsoon via surface cooling and atmospheric ventilation. Geophys. Res. Lett. 44: 5113-5122.

99. D’Agostino, R., J. Bader, S. Bordoni, et al. 2019. Northern Hemisphere monsoon response to mid-Holocene orbital forcing and greenhouse gas-induced global warming. Geophys. Res. Lett. 46: 1591-1601.

100. Morrill, C., D.P. Lowry \& A. Hoell. 2018. Thermodynamic and dynamic causes of pluvial conditions during the Last Glacial Maximum in Western North America. Geophys. Res. Lett. 45: 335-345.

101. Lora, J.M. 2018. Components and mechanisms of hydrologic cycle changes over North America at the Last Glacial Maximum. J. Clim. 31: 7035-7051.

102. Oster, J.L., D.E. Ibarra, M.J. Winnick, et al. 2015. Steering of westerly storms over western North America at the Last Glacial Maximum. Nat. Geosci. 8: 201-205.

103. Greve, P., B. Orlowsky, B. Mueller, et al. 2014. Global assessment of trends in wetting and drying over land. Nat. Geosci. 7: 716-721.

104. Scheff, J. \& D.M.W. Frierson. 2015. Terrestrial aridity and its response to greenhouse warming across CMIP5 climate models. J. Clim. 28: 5583-5600.

105. Greve, P. \& S.I. Seneviratne. 2015. Assessment of future changes in water availability and aridity. Geophys. Res. Lett. 42: 5493-5499.

106. Kumar, S., R.P. Allan, F. Zwiers, et al. 2015. Revisiting trends in wetness and dryness in the presence of internal climate variability and water limitations over land. Geophys. Res. Lett. 42: 10,867-10,875.

107. Dai, A., T. Zhao \& J. Chen. 2018. Climate change and drought: a precipitation and evaporation perspective. Curr. Clim. Chang. Rep. 4: 301-312.

108. Byrne, M.P. \& P.A. O’Gorman. 2016. Understanding decreases in land relative humidity with global warming: conceptual model and GCM simulations. J. Clim. 29: 90459061.

109. Lambert, F.H., A.J. Ferraro \& R. Chadwick. 2017. Landocean shifts in tropical precipitation linked to surface temperature and humidity change. J. Clim. 30: 45274545 .

110. Berg, A. \& J. Sheffield. 2018. Soil moistureevapotranspiration coupling in CMIP5 models: relationship with simulated climate and projections. J. Clim. 31: $4865-4878$.

111. Kumar, S., M. Newman, Y. Wang, et al. 2019. Potential reemergence of seasonal soil moisture anomalies in North America. J. Clim. 32: 2707-2734.

112. Ukkola, A.M., I.C. Prentice, T.F. Keenan, et al. 2016. Reduced streamflow in water-stressed climates consistent with $\mathrm{CO}_{2}$ effects on vegetation. Nat. Clim. Chang. 6: 7578.

113. Swann, A.L.S., F.M. Hoffman, C.D. Koven, et al. 2016. Plant responses to increasing $\mathrm{CO}_{2}$ reduce estimates of climate 
impacts on drought severity. Proc. Natl. Acad. Sci. USA 113: 10019-10024.

114. Bonfils, C., G. Anderson, B.D. Santer, et al. 2017. Competing influences of anthropogenic warming, ENSO, and plant physiology on future terrestrial aridity. J. Clim. 30: 68836904.

115. Mankin, J.S., R. Seager, J.E. Smerdon, et al. 2018. Blue water trade-offs with vegetation in a $\mathrm{CO}_{2}$-enriched climate. Geophys. Res. Lett. 45: 3115-3125.

116. Peters, W., I.R. van der Velde, E. van Schaik, et al. 2018. Increased water-use efficiency and reduced $\mathrm{CO}_{2}$ uptake by plants during droughts at a continental scale. Nat. Geosci. 11: 744-748.

117. Berg, A., J. Sheffield \& P.C.D. Milly. 2017. Divergent surface and total soil moisture projections under global warming. Geophys. Res. Lett. 44: 236-244.

118. Chadwick, R., H. Douville \& C.B. Skinner. 2017. Timeslice experiments for understanding regional climate projections: applications to the tropical hydrological cycle and European winter circulation. Clim. Dyn. 49: 30113029.

119. Kooperman, G.J., Y. Chen, F.M. Hoffman, et al. 2018. Forest response to rising $\mathrm{CO}_{2}$ drives zonally asymmetric rainfall change over tropical land. Nat. Clim. Chang. 8: 434440.

120. Yang, Y., M.L. Roderick, S. Zhang, et al. 2018. Hydrologic implications of vegetation response to elevated $\mathrm{CO}_{2}$ in climate projections. Nat. Clim. Chang. 9: 44-48.

121. Mankin, J.S., R. Seager, J.E. Smerdon, et al. 2019. Midlatitude freshwater availability reduced by projected vegetation responses to climate change. Nat. Geosci. 12: 983-988.

122. Grafton, R.Q., J. Williams, C.J. Perry, et al. 2018. The paradox of irrigation efficiency. Science 361: 748-750.

123. Chadwick, R., P. Good, G. Martin, et al. 2016. Large rainfall changes consistently projected over substantial areas of tropical land. Nat. Clim. Chang. 6: 177-181.

124. Chou, C., J.C.H. Chiang, C.W.C.-W. Lan, et al. 2013. Increase in the range between wet and dry season precipitation. Nat. Geosci. 6: 263-267.

125. Chavaillaz, Y., S. Joussaume, S. Bony, et al. 2016. Spatial stabilization and intensification of moistening and drying rate patterns under future climate change. Clim. Dyn. 47: 951965.

126. Dong, L., L.R. Leung \& F. Song. 2018. Future changes of subseasonal precipitation variability in North America during winter under global warming. Geophys. Res. Lett. 45: $12,467-12,476$.

127. Ficklin, D.L., J.T. Abatzoglou \& K.A. Novick. 2019. A new perspective on terrestrial hydrologic intensity that incorporates atmospheric water demand. Geophys. Res. Lett. 46: 8114-8124.

128. Kao, A., X. Jiang, L. Li, et al. 2017. Precipitation, circulation, and cloud variability over the past two decades. Earth Sp. Sci. 4: 597-606.

129. Lan, C.W., M.H. Lo, C.A. Chen, et al. 2019. The mechanisms behind changes in the seasonality of global precipitation found in reanalysis products and CMIP5 simulations. Clim. Dyn. 53: 4173-4187.
130. Liu, C. \& R.P. Allan. 2013. Observed and simulated precipitation responses in wet and dry regions 1850-2100. Environ. Res. Lett. 8: 034002.

131. Marvel, K., B.I. Cook, C.J.W. Bonfils, et al. 2019. Twentiethcentury hydroclimate changes consistent with human influence. Nature 569: 59-65.

132. Polson, D. \& G.C. Hegerl. 2017. Strengthening contrast between precipitation in tropical wet and dry regions. Geophys. Res. Lett. 44: 365-373.

133. Zhang, Y. \& S. Fueglistaler. 2019. Mechanism for increasing tropical rainfall unevenness with global warming. Geophys. Res. Lett. 46: 14836-14843.

134. Alter, R.E., E.S. Im \& E.A.B. Eltahir. 2015. Rainfall consistently enhanced around the Gezira Scheme in East Africa due to irrigation. Nat. Geosci. 8: 763-767.

135. De Vrese, P., S. Hagemann \& M. Claussen. 2016. Asian irrigation, African rain: remote impacts of irrigation. Geophys. Res. Lett. 43: 3737-3745.

136. Wang-Erlandsson, L., I. Fetzer, P.W. Keys, et al. 2018. Remote land use impacts on river flows through atmospheric teleconnections. Hydrol. Earth Syst. Sci. 22: 43114328.

137. Pei, L., N. Moore, S. Zhong, et al. 2016. Effects of irrigation on summer precipitation over the United States. J. Clim. 29: 3541-3558.

138. Wey, H.W., M.H. Lo, S.Y. Lee, et al. 2015. Potential impacts of wintertime soil moisture anomalies from agricultural irrigation at low latitudes on regional and global climates. Geophys. Res. Lett. 42: 8605-8614.

139. Tian, D., W. Dong, D. Gong, et al. 2017. Fast responses of climate system to carbon dioxide, aerosols and sulfate aerosols without the mediation of SST in the CMIP5. Int. J. Climatol. 37: 1156-1166.

140. Richardson, T.B., P.M. Forster, T. Andrews, et al. 2018. Carbon dioxide physiological forcing dominates projected Eastern Amazonian drying. Geophys. Res. Lett. 45: 28152825.

141. Li, X. \& M. Ting. 2017. Understanding the Asian summer monsoon response to greenhouse warming: the relative roles of direct radiative forcing and sea surface temperature change. Clim. Dyn. 49: 2863-2880.

142. Hodnebrog, Ø., G. Myhre, P.M. Forster, et al. 2016. Local biomass burning is a dominant cause of the observed precipitation reduction in southern Africa. Nat. Commun. 7: 11236.

143. He, J. \& B.J. Soden. 2015. Anthropogenic weakening of the tropical circulation: the relative roles of direct $\mathrm{CO}_{2}$ forcing and sea surface temperature change. J. Clim. 28: 87288742 .

144. Wilcox, L., N. Dunstone, A. Lewinschal, et al. 2019. Mechanisms for a remote response to Asian aerosol emissions in boreal winter. Atmos. Chem. Phys. 19: 9081-9095.

145. Dagan, G., P. Stier \& D. Watson-Parris. 2019. Contrasting response of precipitation to aerosol perturbation in the tropics and extra-tropics explained by energy budget considerations. Geophys. Res. Lett. 46: 7828-7837.

146. Patil, N., C. Venkataraman, K. Muduchuru, et al. 2019. Disentangling sea-surface temperature and anthropogenic 
aerosol influences on recent trends in South Asian monsoon rainfall. Clim. Dyn. 52: 2287-2302.

147. Sillmann, J., C.W. Stjern, G. Myhre, et al. 2019. Extreme wet and dry conditions affected differently by greenhouse gases and aerosols. npj Clim. Atmos. Sci. 2: 24.

148. Ma, J., R. Chadwick, K.-H. Seo, et al. 2018. Responses of the tropical atmospheric circulation to climate change and connection to the hydrological cycle. Annu. Rev. Earth Planet. Sci. 46: 549-580.

149. Zhang, B. \& B.J. Soden. 2019. Constraining climate model projections of regional precipitation change. Geophys. Res. Lett. 46: 10522-10531.

150. DiNezio, P.N., J.E. Tierney, B.L. Otto-Bliesner, et al. 2018. Glacial changes in tropical climate amplified by the Indian Ocean. Sci. Adv. 4: eaat9658.

151. Sohn, B.J., S.W. Yeh, J. Schmetz, et al. 2013. Observational evidences of Walker circulation change over the last 30 years contrasting with GCM results. Clim. Dyn. 40: 17211732.

152. L'Heureux, M.L., S. Lee \& B. Lyon. 2013. Recent multidecadal strengthening of the Walker circulation across the tropical Pacific. Nat. Clim. Chang. 3: 571-576.

153. Plesca, E., S.A. Buehler \& V. Grützun. 2018. The fast response of the tropical circulation to $\mathrm{CO}_{2}$ forcing. J. Clim. https://doi.org/10.1175/JCLI-D-18-0086.1.

154. Shaw, T.A. \& Z. Tan. 2018. Testing latitudinally-dependent explanations of the circulation response to increased $\mathrm{CO}_{2}$ using aquaplanet models. Geophys. Res. Lett. 45: 98619869.

155. Xia, Y. \& Y. Huang. 2017. Differential radiative heating drives tropical atmospheric circulation weakening. Geophys. Res. Lett. 44: 10,592-10,600.

156. Merlis, T.M. 2015. Direct weakening of tropical circulations from masked $\mathrm{CO}_{2}$ radiative forcing. Proc. Natl. Acad. Sci. USA https://doi.org/10.1073/pnas.1508268112.

157. Wills, R.C., X.J. Levine \& T. Schneider. 2017. Local energetic constraints on Walker circulation strength. J. Atmos. Sci. 74: 1907-1922.

158. Chemke, R. \& L.M. Polvani. 2019. Exploiting the abrupt $4 \times \mathrm{CO}_{2}$ scenario to elucidate tropical expansion mechanisms. J. Clim. 32: 859-875.

159. Adam, O., T. Schneider, F. Brient, et al. 2016. Relation of the double-ITCZ bias to the atmospheric energy budget in climate models. Geophys. Res. Lett. 43: 7670-7677.

160. Boos, W.R. \& R.L. Korty. 2016. Regional energy budget control of the intertropical convergence zone and application to mid-Holocene rainfall. Nat. Geosci. 9: 892-897.

161. Byrne, M.P., A.G. Pendergrass \& A.D. Rapp. 2018. Response of the intertropical convergence zone to climate change: location, width and strength precipitation climatology. Curr. Clim. Chang. Rep. 4: 355-370.

162. Frierson, D.M.W., Y.T. Hwang, N.S. Fučkar, et al. 2013. Contribution of ocean overturning circulation to tropical rainfall peak in the Northern Hemisphere. Nat. Geosci. 6: 940-944.

163. Loeb, N.G., H. Wang, A. Cheng, et al. 2016. Observational constraints on atmospheric and oceanic cross-equatorial heat transports: revisiting the precipitation asymmetry problem in climate models. Clim. Dyn. 46: 3239-3257.
164. Stephens, G.L., D. O’Brien, P.J. Webster, et al. 2015. The albedo of Earth. Rev. Geophys. 53: 141-163.

165. Ham, Y.G., J.S. Kug, J.Y. Choi, et al. 2018. Inverse relationship between present-day tropical precipitation and its sensitivity to greenhouse warming. Nat. Clim. Chang. 8: 64-69.

166. Watt-Meyer, O. \& D.M.W. Frierson. 2019. ITCZ width controls on Hadley cell extent and eddy-driven jet position and their response to warming. J. Clim. 32: 1151-1166.

167. Samanta, D., K.B. Karnauskas \& N.F. Goodkin. 2019. Tropical Pacific SST and ITCZ biases in climate models: double trouble for future rainfall projections? Geophys. Res. Lett. 46: 2242-2252.

168. Allen, R.J., A.T. Evan, B.B.B.B. Booth, et al. 2015. Interhemispheric aerosol radiative forcing and tropical precipitation shifts during the late twentieth century. J. Clim. 28: 8219-8246.

169. Brönnimann, S., A.M. Fischer, E. Rozanov, et al. 2015. Southward shift of the northern tropical belt from 1945 to 1980. Nat. Geosci. 8: 969-974.

170. Undorf, S., D. Polson, M.A. Bollasina, et al. 2018. Detectable impact of local and remote anthropogenic aerosols on the 20th century changes of West African and South Asian monsoon precipitation. J. Geophys. Res. Atmos. 123: 4871-4889.

171. Hwang, Y.T., D.M.W. Frierson \& S.M. Kang. 2013. Anthropogenic sulfate aerosol and the southward shift of tropical precipitation in the late 20th century. Geophys. Res. Lett. 40: $2845-2850$.

172. McGee, D., A. Donohoe, J. Marshall, et al. 2014. Changes in ITCZ location and cross-equatorial heat transport at the Last Glacial Maximum, Heinrich Stadial 1, and the midHolocene. Earth Planet. Sci. Lett. 390: 69-79.

173. Wodzicki, K.R. \& A.D. Rapp. 2016. Long-term characterization of the Pacific ITCZ using TRMM, GPCP, and ERAInterim. J. Geophys. Res. Atmos. 121: 3153-3170.

174. Alfaro-Sánchez, R., H. Nguyen, S. Klesse, et al. 2018. Climatic and volcanic forcing of tropical belt northern boundary over the past 800 years. Nat. Geosci. 11: 933-938.

175. Kageyama, M., U. Merkel, B. Otto-Bliesner, et al. 2013. Climatic impacts of fresh water hosing under Last Glacial Maximum conditions: a multi-model study. Clim. Past 9: 935-953.

176. Parsons, L.A., J. Yin, J.T. Overpeck, et al. 2014. Influence of the Atlantic Meridional Overturning Circulation on the monsoon rainfall and carbon balance of the American tropics. Geophys. Res. Lett. https://doi.org/10.1002/ 2013GL058454.

177. Byrne, M.P. \& T. Schneider. 2016. Narrowing of the ITCZ in a warming climate: physical mechanisms. Geophys. Res. Lett. 43: 11,350-11,357.

178. Harrop, B.E. \& D.L. Hartmann. 2016. The role of cloud radiative heating in determining the location of the ITCZ in aquaplanet simulations. J. Clim. https://doi.org/10.1175/ JCLI-D-15-0521.1.

179. Popp, M. \& L.G. Silvers. 2017. Double and single ITCZs with and without clouds. J. Clim. https://doi.org/10.1175/ JCLI-D-17-0062.1.

180. Dixit, V., O. Geoffroy \& S.C. Sherwood. 2018. Control of ITCZ width by low-level radiative heating from upper-level 
clouds in aquaplanet simulations. Geophys. Res. Lett. 10: 5788-5797.

181. Lau, W.K.M. \& K.-M. Kim. 2015. Robust Hadley circulation changes and increasing global dryness due to $\mathrm{CO}_{2}$ warming from CMIP5 model projections. Proc. Natl. Acad. Sci. USA 112: 3630-3635.

182. Chung, E.S. \& B.J. Soden. 2017. Hemispheric climate shifts driven by anthropogenic aerosol-cloud interactions. Nat. Geosci. 10: 566-571.

183. Dong, B. \& R. Sutton. 2015. Dominant role of greenhousegas forcing in the recovery of Sahel rainfall. Nat. Clim. Chang. 5: 757-760.

184. Su, H., J.H. Jiang, J.D. Neelin, et al. 2017. Tightening of tropical ascent and high clouds key to precipitation change in a warmer climate. Nat. Commun. 8: 15771.

185. Talib, J., S.J. Woolnough, N.P. Klingaman, et al. 2018. The role of the cloud radiative effect in the sensitivity of the intertropical convergence zone to convective mixing. $J$. Clim. 31: 6821-6838.

186. Su, H., C. Zhai, J.H. Jiang, et al. 2019. A dichotomy between model responses of tropical ascent and descent to surface warming. npj Clim. Atmos. Sci. https://doi.org/10.1038/ s41612-019-0066-8.

187. Byrne, M.P. \& T. Schneider. 2016. Energetic constraints on the width of the intertropical convergence zone. J. Clim. https://doi.org/10.1175/JCLI-D-15-0767.1.

188. Denniston, R.F., C.C. Ummenhofer, A.D. Wanamaker, et al. 2016. Expansion and contraction of the Indo-Pacific tropical rain belt over the last three millennia. Sci. Rep. 6: 34485 .

189. Singarayer, J.S., P.J. Valdes \& W.H.G. Roberts. 2017. Ocean dominated expansion and contraction of the late Quaternary tropical rainbelt. Sci. Rep. 7: 9382.

190. Biasutti, M., A. Voigt, W.R. Boos, et al. 2018. Global energetics and local physics as drivers of past, present and future monsoons. Nat. Geosci. 11: 392-400.

191. Christensen, J.H., K. Krishna Kumar, E. Aldrian, et al. 2013. Climate phenomena and their relevance for future regional climate change. In Climate Change 2013: The Physical Science Basis. Contribution of Working Group I to the Fifth Assessment Report of the Intergovernmental Panel on Climate Change. T.F. Stocker, D. Qin, G.-K. Plattner, et al., Eds.: 1217-1308. Cambridge, UK and New York, NY: Cambridge University Press.

192. Endo, H., A. Kitoh \& H. Ueda. 2018. A unique feature of the Asian summer monsoon response to global warming: the role of different land-sea thermal contrast change between the lower and upper troposphere. SOLA 14: 57-63.

193. Li, Z., W.K.M. Lau, V. Ramanathan, et al. 2016. Aerosol and monsoon climate interactions over Asia. Rev. Geophys. 54: 866-929.

194. Polson, D., M. Bollasina, G.C. Hegerl, et al. 2014. Decreased monsoon precipitation in the Northern Hemisphere due to anthropogenic aerosols. Geophys. Res. Lett. 41: 60236029.

195. Guo, L., A.G. Turner \& E.J. Highwood. 2016. Local and remote impacts of aerosol species on Indian summer monsoon rainfall in a GCM. J. Clim. 29: 6937-6955.

196. Zhou, W., S.-P. Xie \& D. Yang. 2019. Enhanced equatorial warming causes deep-tropical contraction and subtropi- cal monsoon shift. Nat. Clim. Chang. 9. https://doi.org/10. 1038/s41558-019-0603-9.

197. Persad, G.G., D.J. Paynter, Y. Ming, et al. 2017. Competing atmospheric and surface-driven impacts of absorbing aerosols on the East Asian summertime climate. J. Clim. 30: 8929-8949.

198. Seth, A., A. Giannini, M. Rojas, et al. 2019. Monsoon responses to climate changes-connecting past, present and future. Curr. Clim. Chang. Rep. 5: 63-79.

199. Bhattacharya, T., J.E. Tierney, J.A. Addison, et al. 2018. Ice-sheet modulation of deglacial North American monsoon intensification. Nat. Geosci. https://doi.org/10.1038/ s41561-018-0220-7.

200. Grise, K.M., S.M. Davis, I.R. Simpson, et al. 2019. Recent tropical expansion: natural variability or forced response? J. Clim. 32: 1551-1571.

201. Davis, N.A., D.J. Seidel, T. Birner, et al. 2016. Changes in the width of the tropical belt due to simple radiative forcing changes in the GeoMIP simulations. Atmos. Chem. Phys. 16: 10083-10095.

202. Watt-Meyer, O., D.M.W. Frierson \& Q. Fu. 2019. Hemispheric asymmetry of tropical expansion under $\mathrm{CO}_{2}$ forcing. Geophys. Res. Lett. https://doi.org/10.1029/2019 GL083695.

203. Allen, R.J., S.C. Sherwood, J.R. Norris, et al. 2012. Recent Northern Hemisphere tropical expansion primarily driven by black carbon and tropospheric ozone. Nature 485: 350354.

204. Vallis, G.K., P. Zurita-Gotor, C. Cairns, et al. 2015. Response of the large-scale structure of the atmosphere to global warming. Q. J. R. Meteorol. Soc. 141: 14791501.

205. Barnes, E.A. \& L. Polvani. 2013. Response of the midlatitude jets, and of their variability, to increased greenhouse gases in the CMIP5 models. J. Clim. 26: 7117-7135.

206. Cohen, J., J.A. Screen, J.C. Furtado, et al. 2014. Recent Arctic amplification and extreme mid-latitude weather. Nat. Geosci. 7: 627-637.

207. Woollings, T., D. Barriopedro, J. Methven, et al. 2018. Blocking and its response to climate change. Curr. Clim. Chang. Rep. 4: 287-300.

208. Hoskins, B. \& T. Woollings. 2015. Persistent extratropical regimes and climate extremes. Curr. Clim. Chang. Rep. 1: $115-124$.

209. Henderson, G.R., Y. Peings, J.C. Furtado, et al. 2018. Snowatmosphere coupling in the Northern Hemisphere. Nat. Clim. Chang. 8: 954-963.

210. Tang, Q., X. Zhang \& J.A. Francis. 2014. Extreme summer weather in northern mid-latitudes linked to a vanishing cryosphere. Nat. Clim. Chang. 4: 45-50.

211. Pfleiderer, P., C. Schleussner \& D. Coumou. 2018. Boreal summer weather becomes more persistent in a warmer world. Nat. Clim. Chang. 9: 666-671.

212. Routson, C.C., N.P. McKay, D.S. Kaufman, et al. 2019. Midlatitude net precipitation decreased with Arctic warming during the Holocene. Nature 568: 83-87.

213. Dai, A. \& M. Song. 2020. Little influence of Arctic amplification on mid-latitude climate. Nat. Clim. Chang. 10: 231237. 
214. Blackport, R. \& J.A. Screen. 2020. Insignificant effect of Arctic amplification on the amplitude of midlatitude atmospheric waves. Sci. Adv. 6: eaay2880.

215. O'Gorman, P.A. 2015. Precipitation extremes under climate change. Curr. Clim. Chang. Rep. 1: 49-59.

216. Fischer, E.M. \& R. Knutti. 2016. Observed heavy precipitation increase confirms theory and early models. Nat. Clim. Chang. 6: 986-991.

217. Neelin, J.D., S. Sahany, S.N. Stechmann, et al. 2017. Global warming precipitation accumulation increases above the current-climate cutoff scale. Proc. Natl. Acad. Sci. USA 114: 1258-1263.

218. Pendergrass, A.G., K.A. Reed \& B. Medeiros. 2016. The link between extreme precipitation and convective organization in a warming climate: global radiative-convective equilibrium simulations. Geophys. Res. Lett. 43: 11,44511,452 .

219. Pfahl, S., P.A. O'Gorman \& E.M. Fischer. 2017. Understanding the regional pattern of projected future changes in extreme precipitation. Nat. Clim. Chang. 7: 423427.

220. Stephens, E., J.J. Day, F. Pappenberger, et al. 2015. Precipitation and floodiness. Geophys. Res. Lett. 42: 10316-10323.

221. Emerton, R., H.L. Cloke, E.M. Stephens, et al. 2017. Complex picture for likelihood of ENSO-driven flood hazard. Nat. Commun. 8: 14796.

222. Woldemeskel, F. \& A. Sharma. 2016. Should flood regimes change in a warming climate? The role of antecedent moisture conditions. Geophys. Res. Lett. 43: 7556-7563.

223. McColl, K.A., S.H. Alemohammad, R. Akbar, et al. 2017. The global distribution and dynamics of surface soil moisture. Nat. Geosci. 10: 100-104.

224. Wasko, C. \& R. Nathan. 2019. Influence of changes in rainfall and soil moisture on trends in flooding. J. Hydrol. 575: 432-441.

225. Blöschl, G., J. Hall, A. Viglione, et al. 2019. Changing climate both increases and decreases European floods. Nature 573: 108-111.

226. Berghuijs, W.R., S. Harrigan, P. Molnar, et al. 2019. The relative importance of different flood-generating mechanisms across Europe. Water Resour. Res. 55: 4582-4593.

227. Dacre, H.F., P.A. Clark, O. Martinez-Alvarado, et al. 2015. How do atmospheric rivers form? Bull. Am. Meteorol. Soc. 96: $1243-1255$.

228. Ralph, F.M., M.C.L.D. Dettinger, M.M. Cairns, et al. 2018. Defining "atmospheric river": how the glossary of meteorology helped resolve a debate. Bull. Am. Meteorol. Soc. 99: 837-839.

229. Waliser, D. \& B. Guan. 2017. Extreme winds and precipitation during landfall of atmospheric rivers. Nat. Geosci. 10: 179-183.

230. Paltan, H., D. Waliser, W.H. Lim, et al. 2017. Global floods and water availability driven by atmospheric rivers. Geophys. Res. Lett. 44: 10,387-10,395.

231. Froidevaux, P. \& O. Martius. 2016. Exceptional integrated vapour transport toward orography: an important precursor to severe floods in Switzerland. Q. J. R. Meteorol. Soc. 142: $1997-2012$.
232. Lavers, D.A., R.P. Allan, E.F. Wood, et al. 2011. Winter floods in Britain are connected to atmospheric rivers. Geophys. Res. Lett. 38. https://doi.org/10.1029/2011GL049783.

233. Adusumilli, S., A.A. Borsa, M.A. Fish, et al. 2019. A decade of terrestrial water storage changes across the contiguous United States from GPS and GRACE. Geophys. Res. Lett. 46: 13006-13015.

234. Mattingly, K.S., T.L. Mote \& X. Fettweis. 2018. Atmospheric river impacts on Greenland Ice Sheet surface mass balance. J. Geophys. Res. Atmos. 123: 8538-8560.

235. Oltmanns, M., F. Straneo \& M. Tedesco. 2019. Increased Greenland melt triggered by large-scale, year-round precipitation events. Cryosphere 13: 815-825.

236. Little, K., D.G. Kingston, N.J. Cullen, et al. 2019. The role of atmospheric rivers for extreme ablation and snowfall events in the Southern Alps of New Zealand. Geophys. Res. Lett. 46: 2761-2771.

237. Wille, J.D., V. Favier, A. Dufour, et al. 2019. West Antarctic surface melt triggered by atmospheric rivers. Nat. Geosci. 12: 911-916.

238. Espinoza, V., D.E. Waliser, B. Guan, et al. 2018. Global analysis of climate change projection effects on atmospheric rivers. Geophys. Res. Lett. 45: 4299-4308.

239. Lavers, D.A., R.P. Allan, G. Villarini, et al. 2013. Future changes in atmospheric rivers and their implications for winter flooding in Britain. Environ. Res. Lett. 8: 031006.

240. Ramos, A.M., R. Tomé, R.M. Trigo, et al. 2016. Projected changes in atmospheric rivers affecting Europe in CMIP5 models. Geophys. Res. Lett. 43: 9315-9323.

241. Gershunov, A., T.M. Shulgina, R.E.S. Clemesha, et al. 2019. Precipitation regime change in Western North America: the role of atmospheric rivers. Sci. Rep. 9: 9944.

242. O'Gorman, P.A. 2014. Contrasting responses of mean and extreme snowfall to climate change. Nature 512: 416418.

243. Turner, J., T. Phillips, M. Thamban, et al. 2019. The dominant role of extreme precipitation events in Antarctic snowfall variability. Geophys. Res. Lett. 46: 3502-3511

244. Wu, X., T. Che, X. Li, et al. 2018. Slower snowmelt in spring along with climate warming across the Northern Hemisphere. Geophys. Res. Lett. 45: 12,331-12,339.

245. Pall, P., L.M. Tallaksen \& F. Stordal. 2019. A climatology of rain-on-snow events for Norway. J. Clim. 32: 6995-7016.

246. Musselman, K.N., F. Lehner, K. Ikeda, et al. 2018. Projected increases and shifts in rain-on-snow flood risk over western North America. Nat. Clim. Chang. 8: 808-812.

247. Musselman, K.N., M.P. Clark, C. Liu, et al. 2017. Slower snowmelt in a warmer world. Nat. Clim. Chang. 7:214-219.

248. Zeng, X., P. Broxton \& N. Dawson. 2018. Snowpack change from 1982 to 2016 over conterminous United States. Geophys. Res. Lett. https://doi.org/10.1029/2018GL079621.

249. Rhoades, A.M., A.D. Jones \& P.A. Ullrich. 2018. The changing character of the California Sierra Nevada as a natural reservoir. Geophys. Res. Lett. 45: 13,008-13,019.

250. Lei, Y., T. Yao, K. Yang, et al. 2017. Lake seasonality across the Tibetan Plateau and their varying relationship with regional mass changes and local hydrology. Geophys. Res. Lett. 44: 892-900. 
251. Hock, R., G. Rasul, C. Adler, et al. 2019. High mountain areas. In IPCC Special Report on the Ocean and Cryosphere in a Changing Climate. H.-O. Poörtner, D.C. Roberts, V. Masson-Delmotte, Eds.: 121-202. In press. https://www. ipcc.ch/srocc/chapter/chapter-2/.

252. Muchan, K., M. Lewis, J. Hannaford, et al. 2015. The winter storms of 2013/2014 in the UK: hydrological responses and impacts. Weather 70: 55-61.

253. Zanardo, S., L. Nicotina, A.G.J. Hilberts, et al. 2019. Modulation of economic losses from European floods by the North Atlantic Oscillation. Geophys. Res. Lett. 46: 25632572.

254. Nikumbh, A., A. Chakraborty \& G.S. Bhat. 2019. Recent spatial aggregation tendency of rainfall extremes over India. Sci. Rep. 9: 1-29.

255. Lenggenhager, S., M. Croci-Maspoli, S. Brönnimann, et al. 2019. On the dynamical coupling between atmospheric blocks and heavy precipitation events: a discussion of the southern Alpine flood in October 2000. Q. J. R. Meteorol. Soc. 145: 530-545.

256. Zhou, C., K. Wang \& D. Qi. 2018. 21. Attribution of the July 2016 extreme precipitation event over China's Wuhan. Bull. Am. Meteorol. Soc. 99: S107-S112.

257. Takahashi, H.G., H. Fujinami, T. Yasunari, et al. 2015. Role of tropical cyclones along the monsoon trough in the 2011 Thai flood and interannual variability. J. Clim. 28: 14651476.

258. Tan, X., T.Y. Gan, S. Chen, et al. 2019. Trends in persistent seasonal-scale atmospheric circulation patterns responsible for seasonal precipitation totals and occurrences of precipitation extremes over Canada. J. Clim. 32: 71057126.

259. Dwyer, J.G. \& P.A. O’Gorman. 2017. Changing duration and spatial extent of midlatitude precipitation extremes across different climates. Geophys. Res. Lett. 44: 5863-5871.

260. Kossin, J.P. 2018. A global slowdown of tropical-cyclone translation speed. Nature 558: 104-107.

261. Moon, I.J., S.H. Kim \& J.C.L. Chan. 2019. Climate change and tropical cyclone trend. Nature 570: E3-E5.

262. Lanzante, J.R. 2019. Uncertainties in tropical-cyclone translation speed. Nature 570: E6-E15.

263. Bevacqua, E., D. Maraun, M.I. Vousdoukas, et al. 2019. Higher probability of compound flooding from precipitation and storm surge in Europe under anthropogenic climate change. Sci. Adv. 5: eaaw5531.

264. Zellou, B. \& H. Rahali. 2019. Assessment of the joint impact of extreme rainfall and storm surge on the risk of flooding in a coastal area. J. Hydrol. 569: 647-665.

265. Phibbs, S. \& R. Toumi. 2016. The dependence of precipitation and its footprint on atmospheric temperature in idealized extratropical cyclones. J. Geophys. Res. 121: 87438754 .

266. Chauvin, F., H. Douville \& A. Ribes. 2017. Atlantic tropical cyclones water budget in observations and CNRM-CM5 model. Clim. Dyn. 49: 4009-4021.

267. Rosenfeld, D., M. Clavner \& R. Nirel. 2011. Pollution and dust aerosols modulating tropical cyclones intensities. Atmos. Res. 102: 66-76.
268. Zhao, C., Y. Lin, F. Wu, et al. 2018. Enlarging rainfall area of tropical cyclones by atmospheric aerosols. Geophys. Res. Lett. 45: 8604-8611.

269. Rosenfeld, D., W.L. Woodley, A. Khain, et al. 2012. Aerosol effects on microstructure and intensity of tropical cyclones. Bull. Am. Meteorol. Soc. 93: 987-1001.

270. Qu, Y., B. Chen, J. Ming, et al. 2017. Aerosol impacts on the structure, intensity, and precipitation of the Landfalling Typhoon Saomai (2006). J. Geophys. Res. Atmos. 122: $11,825-11,842$.

271. Wang, Y., K.-H. Lee, Y. Lin, et al. 2014. Distinct effects of anthropogenic aerosols on tropical cyclones. Nat. Clim. Chang. 4: 368-373.

272. Khain, A., B. Lynn \& J. Dudhia. 2010. Aerosol effects on intensity of landfalling hurricanes as seen from simulations with the WRF model with spectral bin microphysics. J. Atmos. Sci. https://doi.org/10.1175/2009JAS3210.1.

273. Dunstone, N.J., D.M. Smith, B.B.B. Booth, et al. 2013. Anthropogenic aerosol forcing of Atlantic tropical storms. Nat. Geosci. 6: 534-539.

274. Dunning, C.M., E. Black \& R.P. Allan. 2018. Later wet seasons with more intense rainfall over Africa under future climate change. J. Clim. https://doi.org/10.1175/JCLI-D-180102.1.

275. Ficchì, A. \& L. Stephens. 2019. Climate variability alters flood timing across Africa. Geophys. Res. Lett. 46. https: //doi.org/10.1029/2019GL081988.

276. Dunning, C.M., E.C.L. Black \& R.P. Allan. 2016. The onset and cessation of seasonal rainfall over Africa. J. Geophys. Res. 121: 11405-11424.

277. Taylor, C.M., D. Belusic, F. Guichard, et al. 2017. Frequency of extreme Sahelian storms tripled since 1982 in satellite observations. Nature 544: 475-478.

278. Karmakar, N., A. Chakraborty \& R.S. Nanjundiah. 2017. Increased sporadic extremes decrease the intraseasonal variability in the Indian summer monsoon rainfall. Sci. Rep. 7: 7824 .

279. Roxy, M.K., S. Ghosh, A. Pathak, et al. 2017. A threefold rise in widespread extreme rain events over central India. Nat. Commun. 8: 708. https://doi.org/10.1038/s41467-01700744-9.

280. Taylor, C.M., C.E. Birch, D.J. Parker, et al. 2013. Modeling soil moisture-precipitation feedback in the Sahel: importance of spatial scale versus convective parameterization. Geophys. Res. Lett. 40: 6213-6218.

281. Moon, H., B.P. Guillod, L. Gudmundsson, et al. 2019. Soil moisture effects on afternoon precipitation occurrence in current climate models. Geophys. Res. Lett. 46. https://doi. org/10.1029/2018GL080879.

282. Taylor, C.M. 2015. Detecting soil moisture impacts on convective initiation in Europe. Geophys. Res. Lett. 42: 46314638.

283. Takahashi, H.G. \& J. Polcher. 2019. Weakening of rainfall intensity on wet soils over the wet Asian monsoon region using a high-resolution regional climate model. Prog. Earth Planet. Sci. 6: 26.

284. Xiang, T., E.R. Vivoni \& D.J. Gochis. 2018. Influence of initial soil moisture and vegetation conditions on monsoon 
precipitation events in northwest México. Atmosfera 31: 25-45.

285. Miller, P.W., A. Kumar, T.L. Mote, et al. 2019. Persistent hydrological consequences of Hurricane Maria in Puerto Rico. Geophys. Res. Lett. 46: 1413-1422.

286. Skinner, C.B., C.J. Poulsen, R. Chadwick, et al. 2017. The role of plant $\mathrm{CO}_{2}$ physiological forcing in shaping future daily-scale precipitation. J. Clim. 30: 23192340.

287. Kooperman, G.J., M.D. Fowler, F.M. Hoffman, et al. 2018. Plant physiological responses to rising $\mathrm{CO}_{2}$ modify simulated daily runoff intensity with implications for globalscale flood risk assessment. Geophys. Res. Lett. https://doi. org/10.1029/2018GL079901.

288. Fowler, M.D., G.J. Kooperman, J.T. Randerson, et al. 2019. Identifying the effect of plant-physiological responses to rising $\mathrm{CO}_{2}$ on global streamflow. Nat. Clim. Chang. 9: 873879.

289. Tan, X. \& T.Y. Gan. 2015. Contribution of human and climate change impacts to changes in streamflow of Canada. Sci. Rep. 5: 17767.

290. Levy, M.C., A.V. Lopes, A. Cohn, et al. 2018. Land use change increases streamflow across the arc of deforestation in Brazil. Geophys. Res. Lett. 45: 3520-3530.

291. Dos Santos, V., F. Laurent, C. Abe, et al. 2018. Hydrologic response to land use change in a large basin in eastern Amazon. Water 10: 429.

292. Guzha, A.C., M.C. Rufino, S. Okoth, et al. 2018. Impacts of land use and land cover change on surface runoff, discharge and low flows: evidence from East Africa. J. Hydrol. Reg. Stud. 15: 49-67.

293. Hoegh-Guldberg, O., D. Jacob, M. Taylor, et al. 2019. Impacts of $1.5^{\circ} \mathrm{C}$ global warming on natural and human systems. In IPCC Special Report on the Impacts of Global Warming of $1.5{ }^{\circ} \mathrm{C}$ above Pre-Industrial Levels and Related Global Greenhouse Gas Emission Pathways, in the Context of Strengthening the Global Response to the Threat of Climate Change. V. Masson-Delmotte, P. Zhai, H.-O. Pörtner, et al., Eds.: 175-311. Cambridge, UK and New York, NY: Cambridge University Press.

294. Lejeune, Q., E.L. Davin, B.P. Guillod, et al. 2015. Influence of Amazonian deforestation on the future evolution of regional surface fluxes, circulation, surface temperature and precipitation. Clim. Dyn. 44: 2769-2786.

295. Spracklen, D.V. \& L. Garcia-Carreras. 2015. The impact of Amazonian deforestation on Amazon basin rainfall. Geophys. Res. Lett. 42: 9546-9552.

296. Lawrence, D. \& K. Vandecar. 2015. Effects of tropical deforestation on climate and agriculture. Nat. Clim. Chang. 5: $27-36$.

297. Jiang, P., D. Wang \& Y. Cao. 2016. Spatiotemporal characteristics of precipitation concentration and their possible links to urban extent in China. Theor. Appl. Climatol. 123: 757-768.

298. Sarangi, C., S.N. Tripathi, Y. Qian, et al. 2018. Aerosol and urban land use effect on rainfall around cities in Indo-Gangetic Basin from observations and cloud resolving model simulations. J. Geophys. Res. Atmos. 123: 36453667.
299. Pathirana, A., H.B. Denekew, W. Veerbeek, et al. 2014. Impact of urban growth-driven landuse change on microclimate and extreme precipitation - a sensitivity study. Atmos. Res. 138: 59-72.

300. Schmid, P.E. \& D. Niyogi. 2017. Modeling urban precipitation modification by spatially heterogeneous aerosols. J. Appl. Meteorol. Climatol. 56: 2141-2153.

301. Chen, J., L. Theller, M.W. Gitau, et al. 2017. Urbanization impacts on surface runoff of the contiguous United States. J. Environ. Manage. 187: 470-481.

302. Dou, J., Y. Wang, R. Bornstein, et al. 2015. Observed spatial characteristics of Beijing urban climate impacts on summer thunderstorms. J. Appl. Meteorol. Climatol. 54: $94-$ 105.

303. Freud, E. \& D. Rosenfeld. 2012. Linear relation between convective cloud drop number concentration and depth for rain initiation. J. Geophys. Res. Atmos. 117. https://doi.org/ 10.1029/2011JD016457.

304. Konwar, M., R.S. Maheskumar, J.R. Kulkarni, et al. 2012. Aerosol control on depth of warm rain in convective clouds. J. Geophys. Res. Atmos. 117. https://doi.org/10. 1029/2012JD017585.

305. Braga, R.C., D. Rosenfeld, R. Weigel, et al. 2017. Further evidence for $\mathrm{CCN}$ aerosol concentrations determining the height of warm rain and ice initiation in convective clouds over the Amazon basin. Atmos. Chem. Phys. 17: 1443314456.

306. Thornton, J.A., K.S. Virts, R.H. Holzworth, et al. 2017. Lightning enhancement over major oceanic shipping lanes. Geophys. Res. Lett. 44: 9102-9111.

307. Heikenfeld, M., B. White, L. Labbouz, et al. 2019. Aerosol effects on deep convection: the propagation of aerosol perturbations through convective cloud microphysics. Atmos. Chem. Phys. 19: 2601-2627.

308. Rosenfeld, D., U. Lohmann, G.B. Raga, et al. 2008. Flood or drought: how do aerosols affect precipitation? Science 321: 1309-1313.

309. Koren, I., J.V. Martins, L.A. Remer, et al. 2008. Smoke invigoration versus inhibition of clouds over the Amazon. Science 321: 946-949.

310. Liu, H., J. Guo, I. Koren, et al. 2019. Non-monotonic aerosol effect on precipitation in convective clouds over tropical oceans. Sci. Rep. 9: 7809.

311. Rauber, R.M., B. Geerts, L. Xue, et al. 2019. Wintertime orographic cloud seeding-a review. J. Appl. Meteorol. Climatol. 58: 2117-2140.

312. Wang, Y., A. Khalizov, M. Levy, et al. 2013. New Directions: light absorbing aerosols and their atmospheric impacts. Atmos. Environ. 81: 713-715.

313. Fan, J., D. Rosenfeld, Y. Yang, et al. 2015. Substantial contribution of anthropogenic air pollution to catastrophic floods in Southwest China. Geophys. Res. Lett. 42: 6066-6075.

314. Guo, J., M. Deng, S.S. Lee, et al. 2016. Delaying precipitation and lightning by air pollution over the Pearl River Delta. Part I: observational analyses. J. Geophys. Res. Atmos. 121: 6472-6488.

315. Goswami, B.N., V. Venugopal, D. Sangupta, et al. 2006. Increasing trend of extreme rain events over India in a warming environment. Science 314: 1442-1445. 
316. Guo, J., T. Su, Z. Li, et al. 2017. Declining frequency of summertime local-scale precipitation over eastern China from 1970 to 2010 and its potential link to aerosols. Geophys. Res. Lett. 44: 5700-5708.

317. Qian, Y., D. Gong, J. Fan, et al. 2009. Heavy pollution suppresses light rain in China: observations and modeling. J. Geophys. Res. 114: D00K02.

318. Westra, S., H.J. Fowler, J.P. Evans, et al. 2014. Future changes to the intensity and frequency of short-duration extreme rainfall. Rev. Geophys. 52: 522-555.

319. Romps, D.M. 2016. Clausius-Clapeyron scaling of CAPE from analytical solutions to RCE. J. Atmos. Sci. https://doi. org/10.1175/JAS-D-15-0327.1.

320. Barbero, R., H.J. Fowler, S. Blenkinsop, et al. 2019. A synthesis of hourly and daily precipitation extremes in different climatic regions. Weather Clim. Extrem. 26: 100219.

321. Hamada, A., Y.N. Takayabu, C. Liu, et al. 2015. Weak linkage between the heaviest rainfall and tallest storms. Nat. Commun. 6: 6213.

322. Berg, P., C. Moseley \& J.O. Haerter. 2013. Strong increase in convective precipitation in response to higher temperatures. Nat. Geosci. 6: 181-185.

323. Scoccimarro, E., G. Villarini, M. Vichi, et al. 2015. Projected changes in intense precipitation over Europe at the daily and subdaily time scales. J. Clim. 28: 6193-6203.

324. Molnar, P., S. Fatichi, L. Gaál, et al. 2015. Storm type effects on super Clausius-Clapeyron scaling of intense rainstorm properties with air temperature. Hydrol. Earth Syst. Sci. 19: 1753-1766.

325. Nie, J., A.H. Sobel, D.A. Shaevitz, et al. 2018. Dynamic amplification of extreme precipitation sensitivity. Proc. Natl. Acad. Sci. USA 115: 9467-9472.

326. Prein, A.F., R.M. Rasmussen, K. Ikeda, et al. 2017. The future intensification of hourly precipitation extremes. Nat. Clim. Chang. 7: 48-52.

327. Zhang, Z., F.M. Ralph \& M. Zheng. 2018. The relationship between extratropical cyclone strength and atmospheric river intensity and position. Geophys. Res. Lett. 46: 18141823.

328. Kendon, E.J., R.A. Stratton, S. Tucker, et al. 2019. Enhanced future changes in wet and dry extremes over Africa at convection-permitting scale. Nat. Commun. 10: 1794.

329. Lenderink, G., R. Barbero, J.M. Loriaux, et al. 2017. SuperClausius-Clapeyron scaling of extreme hourly convective precipitation and its relation to large-scale atmospheric conditions. J. Clim. 30: 6037-6052.

330. Guerreiro, S.B., H.J. Fowler, R. Barbero, et al. 2018. Detection of continental-scale intensification of hourly rainfall extremes. Nat. Clim. Chang. 8: 803-807.

331. Burdanowitz, J., S.A. Buehler, S. Bakan, et al. 2019. On the sensitivity of oceanic precipitation to sea surface temperature. Atmos. Chem. Phys. 19: 9241-9252.

332. Formayer, H. \& A. Fritz. 2017. Temperature dependency of hourly precipitation intensities - surface versus cloud layer temperature. Int. J. Climatol. 37: 1-10.

333. van der Wiel, K., N. Wanders, F.M. Selten, et al. 2019. Added value of large ensemble simulations for assessing extreme river discharge in a $2^{\circ} \mathrm{C}$ warmer world. Geophys. Res. Lett. 46: 2093-2102.
334. Zhou, Y., M. Luo \& Y. Leung. 2016. On the detection of precipitation dependence on temperature. Geophys. Res. Lett. 43: 4555-4565.

335. Bao, J., S.C. Sherwood, L.V. Alexander, et al. 2017. Future increases in extreme precipitation exceed observed scaling rates. Nat. Clim. Chang. 7: 128-132.

336. Zhang, X., F.W. Zwiers, G. Li, et al. 2017. Complexity in estimating past and future extreme short-duration rainfall. Nat. Geosci. 10: 255-259.

337. Ali, H., H.J. Fowler \& V. Mishra. 2018. Global observational evidence of strong linkage between dew point temperature and precipitation extremes. Geophys. Res. Lett. https://doi. org/10.1029/2018GL080557.

338. Barbero, R., H.J. Fowler, G. Lenderink, et al. 2017. Is the intensification of precipitation extremes with global warming better detected at hourly than daily resolutions? Geophys. Res. Lett. 44: 974-983.

339. Myhre, G., K. Alterskjær, C.W. Stjern, et al. 2019. Frequency of extreme precipitation increases extensively with event rareness under global warming. Sci. Rep. 9: 16063.

340. Meredith, E.P., U. Ulbrich \& H.W. Rust. 2019. The diurnal nature of future extreme precipitation intensification. Geophys. Res. Lett. 46: 7680-7689.

341. Loriaux, J.M., G. Lenderink \& A. Pier Siebesma. 2017. Large-scale controls on extreme precipitation. J. Clim. 30: 955-968.

342. Tandon, N.F., X. Zhang \& A.H. Sobel. 2018. Understanding the dynamics of future changes in extreme precipitation intensity. Geophys. Res. Lett. 45: 2870-2878.

343. Chan, S.C., E.J. Kendon, N. Roberts, et al. 2018. Largescale predictors for extreme hourly precipitation events in convection-permitting climate simulations. J. Clim. 31: 2115-2131.

344. Baker, H.S., R.J. Millar, D.J. Karoly, et al. 2018. Higher $\mathrm{CO}_{2}$ concentrations increase extreme event risk in a $1.5^{\circ} \mathrm{C}$ world. Nat. Clim. Chang. 8: 267-283.

345. Sandvik, M.I., A. Sorteberg \& R. Rasmussen. 2018. Sensitivity of historical orographically enhanced extreme precipitation events to idealized temperature perturbations. Clim. Dyn. 50: 143-157.

346. Chan, S.C., E.J. Kendon, N.M. Roberts, et al. 2016. The characteristics of summer sub-hourly rainfall over the southern UK in a high-resolution convective permitting model. Environ. Res. Lett. 11: 94024.

347. Eekhout, J.P.C., J.E. Hunink, W. Terink, et al. 2018. Why increased extreme precipitation under climate change negatively affects water security. Hydrol. Earth Syst. Sci. 22: 5935-5946.

348. Yin, J., P. Gentine, S. Zhou, et al. 2018. Large increase in global storm runoff extremes driven by climate and anthropogenic changes. Nat. Commun. 9: 4389.

349. Singh, M.S. \& P.A. O'Gorman. 2014. Influence of microphysics on the scaling of precipitation extremes with temperature. Geophys. Res. Lett. 41: 6037-6044.

350. Bao, J. \& S.C. Sherwood. 2019. The role of convective selfaggregation in extreme instantaneous versus daily precipitation. J. Adv. Model. Earth Syst. 11: 19-33.

351. Jeevanjee, N. \& D.M. Romps. 2019. Mean precipitation change from a deepening troposphere. Proc. Natl. Acad. Sci. USA. 115: 11465-11470. 